\title{
The dichloromethane induced fragmentation of ferrocenylmethyldimethylamine. Mechanistic aspects and crystallographic and electrochemical investigation of the $\left(\mathrm{FcCH}_{2}\right)_{2} \mathrm{NMe}_{2}^{+}$and $\mathrm{FcCH}_{2} \mathrm{NMe}_{2} \mathrm{H}^{+}$ions ${ }^{1}$
}

\author{
Rainer F. Winter ${ }^{\mathrm{a}, *}$, Gotthelf Wolmershäuser ${ }^{\mathrm{b}}$ \\ "Institut für Anorganische Chemie der Universität Stuttgart, Pfaffenwaldring 55, D-70569 Stuttgart, Germany \\ ${ }^{\mathrm{b}}$ Fachbereich Chemie der Universität Kaiserslautern, Erwin-Schrödinger-Str., D-67653 Kaiserslautern, Germany
}

\begin{abstract}
Ferrocenylmethyldimethylamine, $\mathrm{FcCH}_{2} \mathrm{NMe}_{2}$, reacts with $\mathrm{CH}_{2} \mathrm{Cl}_{2}$ in either the presence or absence of non-coordinating counterions to give equimolar amounts of the bis(ferrocenylmethyl)dimethyl ammonium salts $\left(\mathrm{FcCH}_{2}\right)_{2} \mathrm{NMe}_{2}^{+} \mathrm{X}^{-}\left(\mathrm{X}^{-}=\mathrm{PF}_{6}^{-}\right.$, $\mathrm{SbF}_{6}^{-}, \mathrm{BPh}_{4}^{-}$or $\left.\mathrm{Cl}^{-}, \mathbf{1 a}-\mathbf{d}\right)$ and the corresponding protonated ammonium salts $\mathrm{FcCH}_{2} \mathrm{NMe}_{2} \mathrm{H}^{+}$which have been isolated as the $\mathrm{SbF}_{6}^{-}$and $\mathrm{Cl}^{-}$salts $2 \mathbf{b}, \mathbf{d}$. The reaction proceeds via fragmentation of an intermediate quaternary chloromethylated ammonium ion to chloromethylferrocene, $\mathrm{FcCH}_{2} \mathrm{Cl}$, and dimethyliminium chloride $\mathrm{NMe}_{2} \mathrm{CH}_{2}^{+} \mathrm{Cl}^{-}$. The parent amine acts as a nucleophile toward $\mathrm{FcCH}_{2} \mathrm{Cl}$ to give 1a-d and as a base toward $\mathrm{NMe}_{2} \mathrm{CH}_{2}^{+}$to give $\mathrm{FcCH}_{2} \mathrm{NMe}_{2} \mathrm{H}^{+}, \mathrm{NMe}_{2} \mathrm{H}$ and $\left(\mathrm{Me}_{2} \mathrm{~N}\right)_{2} \mathrm{CH}_{2}$. The $\mathrm{FcCH}_{2} \mathrm{Cl}$ intermediate is intercepted by $\mathrm{NEt}_{3}$ while $\mathrm{KCN}$ or $\mathrm{LiH}$ do not successfully compete with $\mathrm{FcCH}_{2} \mathrm{NMe}_{2}$. A new, non-toxic, selective, high-yield route to $1 \mathbf{d}$ is also presented. Electrochemistry and UV-vis spectroelectrochemistry reveal, that the two identical redox centers in $\mathbf{1 a - d}$ are essentially non-interacting. Individual $E_{1 / 2}$ values have been determined for different solvents by digital simulation. The corresponding ferrocenium salts were prepared by either chemical or electrochemical means and accordingly characterized. Our studies are augmented by X-ray structure analyses of $\mathbf{1 b} \mathbf{b} \mathbf{1 d}$ and $\mathbf{2} \mathbf{d}$. $\mathbf{1 d}$ contains three different cation conformers and four molecules of water per unit cell. The latter are hydrogen bonded to the chloride counterions to form one-dimensional infinite chains parallel to the $a$ axis.
\end{abstract}

Keywords: Ferrocenes; Ferrocenium salts; Dichloromethane; Desamination; Voltammetry; X-ray structures

\section{Introduction}

We have recently reported that the putative cationic ruthenium butatrienylidene intermediate $[\mathrm{Ru}]=\mathrm{C}=\mathrm{C}=$ $\mathrm{C}=\mathrm{CH}_{2}^{+}$may be trapped with tertiary amine nucleophiles to give novel Ru-ammoniobutenynyl complexes $[\mathrm{Ru}]-\mathrm{C} \equiv \mathrm{C}-\mathrm{C}\left(\mathrm{NR}_{3}\right)=\mathrm{CH}_{2}^{+} \mathrm{PF}_{6}^{-} \quad\left([\mathrm{Ru}]=\right.$ trans $-\mathrm{Ru}(\mathrm{dppm})_{2}$ $\mathrm{Cl}, \mathrm{R}=\mathrm{Et}, \mathrm{Pr}$ ) in $\mathrm{CH}_{2} \mathrm{Cl}_{2}$ as solvent [1]. Following this line of work we have attempted to incorporate ferro-

\footnotetext{
* Corresponding author. Tel.: + 49711 6854193; fax: +49711 6854165; e-mail: winter@iac.uni-stuttgart.de

${ }^{1}$ Dedicated to Professor Dr Otto J. Scherer on the occasion of his 65th birthday.
}

cenylmethyldimethylamine, $\mathrm{FcCH}_{2} \mathrm{NMe}_{2}$, as an additional reversible redox center into such molecules. An inseparable variety of phosphorus containing products was, however, obtained from which the binuclear ammonium ion $\left(\mathrm{FcCH}_{2}\right)_{2} \mathrm{NMe}_{2}^{+}$was isolated as an orange solid. This was our incentive for initiating an indepth study of the reactivity of $\mathrm{FcCH}_{2} \mathrm{NMe}_{2}$ with $\mathrm{CH}_{2} \mathrm{Cl}_{2}$ itself.

The fact that certain amines are reactive toward $\mathrm{CH}_{2} \mathrm{Cl}_{2}$, and the factors governing their reactivity, have already been well established [2,3]. $N$-methylated tertiary amines of sufficient nucleophilicity readily give the Menschutkin reaction and form crystalline chloromethylammonium salts which directly precipitate from solution 
[2-5]. With secondary amines the reaction is more complex. The corresponding hydrochlorides and bis(diamino)methylene derivatives (aminals) are the most frequently encountered products and usually both are found in the crude reaction mixture. It has been concluded that both evolve from $N$-methylene iminium intermediates $\mathrm{R}_{2} \mathrm{~N}=\mathrm{CH}_{2}^{+}$which, under the reaction conditions, cannot directly be detected [2,6]. This thought is supported by the frequent observation of typical Mannich products as minor or even the major components. More recently the reaction of secondary amines with $\mathrm{CH}_{2} \mathrm{Cl}_{2}$ has evolved into a stratagem for the in situ preparation of iminium salts and their conversion to Mannich products [7-9].

In the course of our investigations we became aware that we had discovered a highly unusual $\mathrm{CH}_{2} \mathrm{Cl}_{2}$ induced fragmentation of a tertiary organometallic amine. Equal proportions of the binuclear $\left(\mathrm{FcCH}_{2}\right)_{2} \mathrm{NMe}_{2}^{+}$and the protonated starting material $\mathrm{FcCH}_{2} \mathrm{NMe}_{2} \mathrm{H}^{+}$are formed in the overall process. It should be noted that none of these cations is really new. The protonated amine is easily available from the reaction with an appropriate dilute acid [10] whereas $\left(\mathrm{FcCH}_{2}\right)_{2} \mathrm{NMe}_{2}^{+} \mathrm{Br}^{-}$has already been obtained by the von Braun cleavage reaction of the parent amine (i.e. its reaction with $\mathrm{BrCN}$ ) [11]. Thus, it is not the products but rather the underlying reaction pathway relating them that constitutes the novelty of our findings. As we will point out, the bis(ferrocenyl-methyl)dimethyl ammonium salt results from the fragmentation of a quaternary chloromethyl ammonium intermediate and the subsequent trapping of the liberated $\mathrm{FcCH}_{2} \mathrm{Cl}$ by the parent amine. In addition we have investigated two of the $\left(\mathrm{FcCH}_{2}\right)_{2} \mathrm{NMe}_{2}^{+}$salts as well as the hydrochloride $\mathrm{FcCH}_{2} \mathrm{NMe}_{2} \mathrm{H}^{+} \mathrm{Cl}^{-}$by $\mathrm{X}$-ray structure analyses. Remarkably, $\left(\mathrm{FcCH}_{2}\right)_{2} \mathrm{NMe}_{2}^{+} \mathrm{Cl}^{-} \cdot 4 / 3 \mathrm{H}_{2} \mathrm{O}$ contains pairs of three different cation conformers and eight molecules of water that are hydrogen bonded to the $\mathrm{Cl}^{-}$counterions per unit cell. Our studies are augmented by electrochemical investigations which reveal two very weakly coupled, reversible redox centers in $\left(\mathrm{FcCH}_{2}\right)_{2} \mathrm{NMe}_{2}^{+}$ and its reductively induced fragmentation as well as the cathodic deprotonation of the hydrochloride. The radical tri- or dications have also been prepared and investigated by ESR and UV-vis spectroscopy. In addition an alternative, non-toxic, high-yield route to $\left(\mathrm{FcCH}_{2}\right)_{2}$ $\mathrm{NMe}_{2}^{+} \mathrm{Cl}^{-}$has been elaborated.

\section{Results and discussion}

\subsection{Formation of the bis(ferrocenylmethyl)dimethyl ammonium salts $\left(\mathrm{FcCH}_{2}\right)_{2} \mathrm{NMe}_{2}^{+} \mathrm{X}^{-}\left(\mathrm{X}^{-}=\mathrm{PF}_{6}^{-}\right.$, $\left.\mathrm{SbF}_{\overline{6}}^{-}, \mathrm{BPh}_{\overline{4}}^{-}(\mathbf{1 a}-\mathrm{c})\right)$}

Our entry into this chemistry came from a reaction aimed at attaching the ferrocenylmethyldimethylamine nucleophile $\left(\mathrm{FcCH}_{2} \mathrm{NMe}_{2}\right)$ as a reversible redox center to the electrophilic $\mathrm{C}_{\gamma}$ of an in situ prepared $[\mathrm{Ru}]=\mathrm{C}=\mathrm{C}=\mathrm{C}=\mathrm{CH}_{2}^{+} \quad$ intermediate $\quad([\mathrm{Ru}]=$ trans $-\mathrm{Ru}-$ $\mathrm{Cl}(\mathrm{dppm})_{2}, \quad \mathrm{dppm}=\mathrm{bis}($ diphenylphosphino)methane $)$ $[1,12]$. $\left(\mathrm{FcCH}_{2}\right)_{2} \mathrm{NMe}_{2}^{+} \mathrm{SbF}_{6}^{-}$(1) $)$proved to be the only isolable compound and was subsequently characterized by NMR, IR and UV-vis spectroscopy as well as by C, $\mathrm{H}, \mathrm{N}$ analysis. Made curious by this unexpected outcome we decided to investigate this reaction in more detail. To these ends we first reacted the parent amine $\mathrm{FcCH}_{2} \mathrm{NMe}_{2}$ with a suspension of $\mathrm{NaSbF}_{6}$ or $\mathrm{NaPF}_{6}$ in $\mathrm{CH}_{2} \mathrm{Cl}_{2}$ under ambient conditions. 1b and $\mathbf{1 a}$ were readily identified and isolated as one of the two products detected by NMR investigation of the crude reaction mixture. We were now concerned that the chemically somewhat unstable suspensions of hexafluoro-ate anions in $\mathrm{CH}_{2} \mathrm{Cl}_{2}$, and more specifically, the fluoride liberated upon their decomposition [13] might be involved in this process and therefore turned to the $\mathrm{BPh}_{4}^{-}$anion. When $\mathrm{FcCH}_{2} \mathrm{NMe}_{2}$ was treated with $\mathrm{NaBPh}_{4}$ in $\mathrm{CH}_{2} \mathrm{Cl}_{2},\left(\mathrm{FcCH}_{2}\right)_{2} \mathrm{NMe}_{2}^{+} \mathrm{BPh}_{4}^{-}$(1c) was obtained in good yield as an orange, analytically pure precipitate. The mother liquor still contained some $1 \mathbf{c}$ and again the same by-product as in the case of $1 \mathbf{a , b}$ as detected by NMR. All our initial attempts to isolate this second component by crystallization from chlorobenzene or chlorobenzene $/ \mathrm{CH}_{3} \mathrm{CN}$ mixtures failed and lead to either pure $1 \mathbf{a}-\mathbf{c}$, mixtures of the two products or, especially upon warming, decomposition as indicated by the precipitation of some dark brown insoluble powder.

The ammonium cations present in $\mathbf{1 a - c}$ exhibit essentially identical spectroscopic properties and, in their IR spectra, besides identical absorptions of the cation those of the respective counterion. Integration of the ${ }^{1} \mathrm{H}-\mathrm{NMR}$ signals indicates that in $\mathbf{1 a - c} \mathrm{NMe}$ and ferrocenylmethyl groups are present in a 1:1 ratio. While all signals are shifted downfield with respect to the parent amine this effect is most pronounced for the methyl and methylene groups which are directly attached to nitrogen (see Table 1). The same holds for the ${ }^{13} \mathrm{C}$ resonances with the notable exception of the ipso carbon of the substituted ferrocene ring which in contrast is shifted by more than 11 ppm toward a higher field. All carbon atoms directly attached to nitrogen are split into non-binomial triplets with couplings to the ${ }^{14} \mathrm{~N}$ nucleus that amount to $4.4 \mathrm{~Hz}$ for the NMe groups and $2.2 \mathrm{~Hz}$ for the $\mathrm{CH}_{2}$ units of the ferrocenylmethyl moiety. Such splitting patterns are characteristic of quaternary ammonium ions [14]. The UV-vis spectra may be regarded as archetypical of the ferrocenyl chromophore with molar absorptivities that are approximately twice as high as for derivatives with only one ferrocenyl moiety per molecule [15] (Table 1). While these observations left little doubt 
Table 1

Spectroscopic data for $\mathrm{FcCH}_{2} \mathrm{NMe}_{2}$, $\left(\mathrm{FcCH}_{2}\right)_{2} \mathrm{NMe}_{2}^{+}(\mathbf{1 a - d})^{\mathbf{a}},\left(\mathrm{FcCH}_{2}\right)_{2} \mathrm{NMe}_{2}^{+} \mathrm{Cl}^{-} \cdot 4 / 3 \mathrm{H}_{2} \mathrm{O}\left(\mathbf{1 d} \cdot 4 / 3 \mathrm{H}_{2} \mathrm{O}\right), \mathrm{FcCH}_{2} \mathrm{NMe}_{2} \mathrm{H}^{+}(\mathbf{2 b}, \mathbf{d})^{\mathrm{a}}$, and $\mathrm{FcCH} \mathrm{NEt}_{3}^{+}(\mathbf{3})$

\begin{tabular}{|c|c|c|c|c|c|c|}
\hline Nucleus & Atom & $\mathrm{FcCH}_{2} \mathrm{NMe}_{2}^{\mathrm{b}}$ & $\left(\mathrm{FcCH}_{2}\right)_{2} \mathrm{NMe}_{2}^{+}$ & $\left(\mathrm{FcCH}_{2}\right)_{2} \mathrm{NMe}_{2}^{+} \cdot 4 / 3 \mathrm{H}_{2} \mathrm{O}$ & $\mathrm{FcCH}_{2} \mathrm{NMe}_{2} \mathrm{H}^{+}$ & $\mathrm{FcCH}_{2} \mathrm{NEt}_{3}^{+}$ \\
\hline \multirow[t]{5}{*}{${ }^{1} \mathrm{H}$} & $\mathrm{NCH}_{3}$ & $2.08(\mathrm{~s}, 6 \mathrm{H})$ & $2.63(\mathrm{~s}, 6 \mathrm{H})$ & $2.69(\mathrm{~s}, 6 \mathrm{H})$ & $2.68(\mathrm{~s}, 6 \mathrm{H})$ & See footnote ${ }^{c}$ \\
\hline & $\mathrm{NCH}_{2}$ & $3.25(\mathrm{~s}, 2 \mathrm{H})$ & $4.22(\mathrm{~s}, 4 \mathrm{H})$ & $4.34(\mathrm{~s}, 4 \mathrm{H})$ & $4.09(\mathrm{~s}, 2 \mathrm{H})$ & $4.20(\mathrm{~s}, 2 \mathrm{H})$ \\
\hline & $\mathrm{Cp}_{\text {unsub }}$ & $4.11(\mathrm{~s}, 5 \mathrm{H})$ & $4.24(\mathrm{~s}, 10 \mathrm{H})$ & $4.25(\mathrm{~s}, 10 \mathrm{H})$ & $4.22(\mathrm{~s}, 5 \mathrm{H})$ & $4.28(\mathrm{~s}, 5 \mathrm{H})$ \\
\hline & $H, \mathrm{C}_{\beta}^{\mathrm{d}}$ & $4.10\left(\mathrm{t},{ }^{3} J_{\mathrm{HH}}=1.77 \mathrm{~Hz}, 2 \mathrm{H}\right)$ & $4.40\left(\mathrm{t},{ }^{3} J_{\mathrm{HH}}=1.82 \mathrm{~Hz}, 4 \mathrm{H}\right)$ & $4.39\left(\mathrm{t},{ }^{3} J_{\mathrm{HH}}=1.85 \mathrm{~Hz}, 4 \mathrm{H}\right)$ & $4.33\left(\mathrm{t},{ }^{3} J_{\mathrm{HH}}=1.82 \mathrm{~Hz}, 2 \mathrm{H}\right)$ & $4.38\left(\mathrm{t},{ }^{3} J_{\mathrm{HH}}=1.85 \mathrm{~Hz}, 2 \mathrm{H}\right)$ \\
\hline & $\begin{array}{l}H, \mathrm{C}_{\alpha}^{\mathrm{d}} \\
\text { Others }\end{array}$ & $4.15\left(\mathrm{t},{ }^{3} J_{\mathrm{HH}}=1.77 \mathrm{~Hz}, 2 \mathrm{H}\right)$ & $4.46\left(\mathrm{t},{ }^{3} J_{\mathrm{HH}}=1.82 \mathrm{~Hz}, 4 \mathrm{H}\right)$ & $\begin{array}{l}4.49\left(\mathrm{t},{ }^{3} J_{\mathrm{HH}}=1.85 \mathrm{~Hz}, 4 \mathrm{H}\right) \\
6.85(\mathrm{vb}, 1 \mathrm{H})\end{array}$ & $4.39\left(\mathrm{t},{ }^{3} J_{\mathrm{HH}}=1.82 \mathrm{~Hz}, 2 \mathrm{H}\right)$ & $4.41\left(\mathrm{t},{ }^{3} J_{\mathrm{HH}}=1.85 \mathrm{~Hz}, 2 \mathrm{H}\right)$ \\
\hline \multirow[t]{6}{*}{${ }^{13} \mathrm{C}$} & $\mathrm{NCH}_{3}$ & 45.0 & $49.1\left(\mathrm{t}, J_{\mathrm{CN}}=4.36 \mathrm{~Hz}\right)$ & $49.0\left(\mathrm{t}, J_{\mathrm{CN}}=4.25 \mathrm{~Hz}\right)$ & 42.9 & See footnote $e^{c}$ \\
\hline & $\mathrm{NCH}_{2}$ & 59.7 & $65.9\left(\mathrm{t}, J_{\mathrm{CN}}=2.25 \mathrm{~Hz}\right)$ & $65.6\left(\mathrm{t}, J_{\mathrm{CN}}=2.05 \mathrm{~Hz}\right)$ & 58.9 & $58.5\left(\mathrm{t}, J_{\mathrm{CN}}=2.1 \mathrm{~Hz}\right)$ \\
\hline & $\mathrm{Cp}_{\text {unsub }}$ & 69.4 & 70.2 & 70.2 & 70.1 & 70.3 \\
\hline & $\mathrm{C}_{\alpha}^{\mathrm{e}}$ & 68.6 & 73.3 & 73.3 & 72.1 & 72.6 \\
\hline & $\mathrm{C}_{\beta}^{\mathrm{e}}$ & 71.0 & 71.5 & 71.4 & 71.0 & 71.3 \\
\hline & $\mathrm{C}_{i p s o}$ & 85.0 & 73.4 & 73.6 & 74.8 & 72.9 \\
\hline \multirow[t]{4}{*}{ UV-vis ${ }^{f}$} & & & $439(245)$ & $436(240)$ & $434(120)$ & \\
\hline & & & $323(180)$ & $323(200)$ & $325(84)$ & \\
\hline & & & $252(6600)$ & $252(6200)$ & $248(2400)$ & \\
\hline & & & $223(10000)$ & $218(8500)$ & $227(3700)$ & \\
\hline
\end{tabular}

a Spectra are independent of the respective counterion.

b For comparison see Ref. [31]

${ }^{\mathrm{c}} \mathrm{NEt}_{3}:{ }^{\prime} \mathrm{H}: 1.25\left(\mathrm{tt},{ }^{3} J_{\mathrm{HH}}=7.26 \mathrm{~Hz},{ }^{3} J_{\mathrm{NH}}=1.84 \mathrm{~Hz}, 9 \mathrm{H}, \mathrm{NCH}_{2} \mathrm{CH}_{3}\right) ; 3.05\left(\mathrm{q},{ }^{3} J_{\mathrm{HH}}=7.26 \mathrm{~Hz}, 6 \mathrm{H}, \mathrm{NCH}_{2} \mathrm{CH}_{3}\right) ;{ }^{13} \mathrm{C}: 7.9\left(\mathrm{NCH}_{2} \mathrm{CH}_{3}\right), 52.8\left(\mathrm{NCH}_{2} \mathrm{CH}_{3}, \mathrm{t}, J_{\mathrm{NC}}=3.1 \mathrm{~Hz}\right)$.

${ }^{d}$ Assignment based on the data for $\mathrm{FcCH}_{2} \mathrm{NMe}_{3}^{+}$in Ref. [32].

e Assignment based on the data for $\mathrm{FcCH}_{2} \mathrm{NMe}_{3}^{+}$and similar ferrocenylmethylamines in Refs. [33] and [36-38]

f $\lambda(\mathrm{nm})\left(\varepsilon\left(\mathrm{M}^{-1} \mathrm{~cm}^{-1}\right)\right)$. 


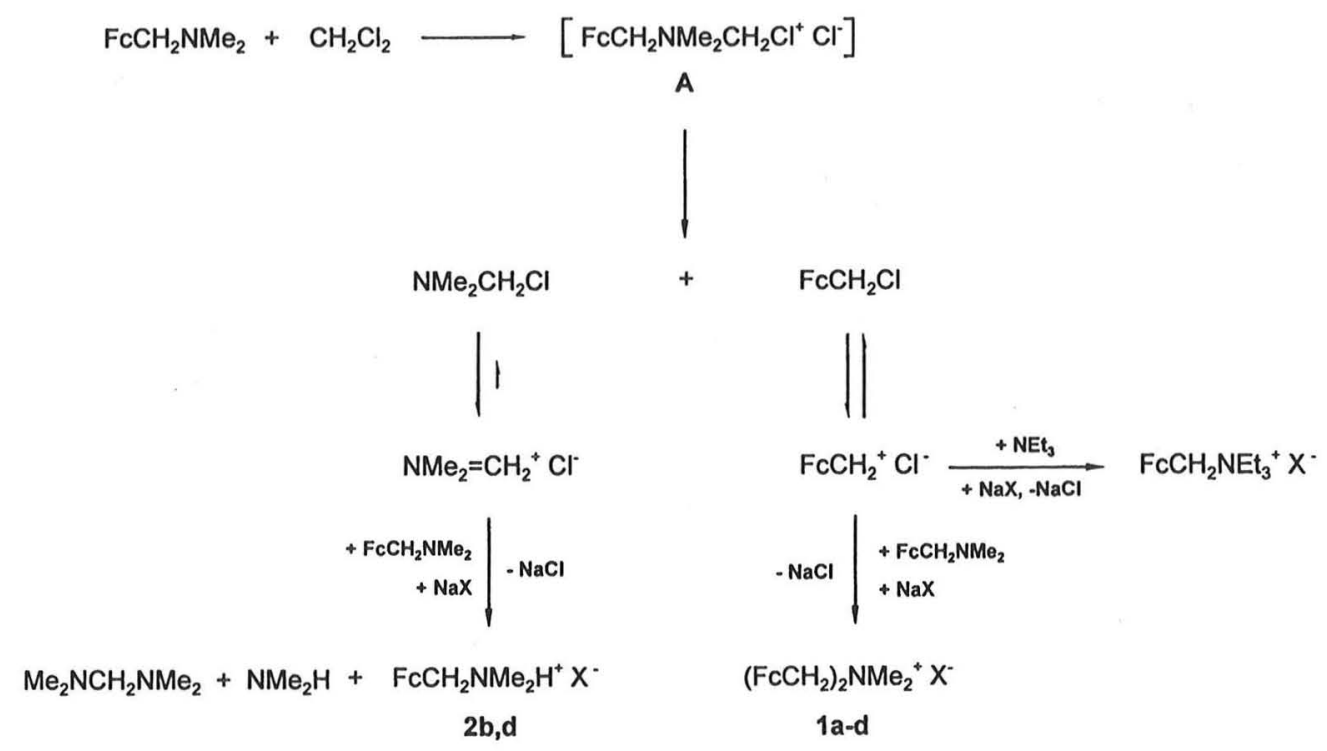

side reactions:

$\mathrm{Me}_{2} \mathrm{NCH}_{2} \mathrm{NMe}_{2}+\mathrm{FcCH}_{2} \mathrm{NMe}_{2} \mathrm{H}^{+} \longrightarrow \mathrm{Me}_{2} \mathrm{NCH}_{2} \mathrm{NMe}_{2} \mathrm{H}^{+}+\mathrm{FCCH}_{2} \mathrm{NMe}_{2}$

$\mathrm{Me}_{2} \mathrm{~N}=\mathrm{CH}_{2}^{+}+2 \mathrm{FcCH}_{2} \mathrm{NMe}_{2} \longrightarrow \mathrm{Me}_{2} \mathrm{NCH}_{2} \mathrm{NMe}_{2}+\left(\mathrm{FCCH}_{2}\right)_{2} \mathrm{NMe}_{2}{ }^{+}$

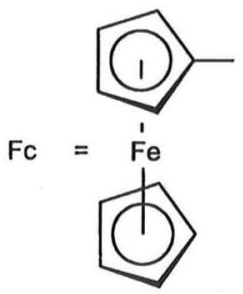

Scheme 1.

as to the identity of $\mathbf{1 a - c}$ the final proof came from an $\mathrm{X}$-ray analysis of $\mathbf{1 b}$ (vide infra).

\subsection{Investigations into the reaction mechanism}

The identical outcome of all reactions regardless of the specific counterion finally brought the role of the solvent into focus. We indeed observed the same reaction as above upon stirring the parent amine in neat $\mathrm{CH}_{2} \mathrm{Cl}_{2}$. The crude product contained a second component with identical NMR signals as before but again only the chloride salt 1d was obtained in moderate yield by crystallization from chlorobenzene $/ \mathrm{CH}_{3} \mathrm{CN}$ mixtures. This spurred our curiosity whether this reaction is unique for $\mathrm{CH}_{2} \mathrm{Cl}_{2}$. In only a brief survey we found that ferrocenylmethyldimethylamine possesses a long term stability in methanol, while it is reactive toward $\mathrm{CHCl}_{3}$, $\mathrm{CH}_{3} \mathrm{CN}$ and $\mathrm{CH}_{3} \mathrm{NO}_{2}$. The reaction with $\mathrm{CHCl}_{3}$ proved to be of special significance to us. Upon stirring a mixture of the parent amine and excess $\mathrm{NaSbF}_{6}$ for 2 days in this solvent an orange suspension gradually formed. After workup a pure compound was obtained which proved to be identical with the as yet unidentified second product of the $\mathrm{CH}_{2} \mathrm{Cl}_{2}$ reaction. It was finally characterized as the protonated ammonium salt $\mathrm{FcCH}_{2} \mathrm{NMe}_{2} \mathrm{H}^{+} \mathrm{SbF}_{6}^{-}$(2b). The hydrochloride 2d was similarly obtained in the absence of $\mathrm{NaSbF}_{6}$. For comparison purposes with $\mathbf{1 b}$ its molecular structure in the solid state was established by $\mathrm{X}$-ray structure analysis (vide infra). The same reaction was also observed in the considerably less acidic $\mathrm{CH}_{3} \mathrm{CN}$ and $\mathrm{CH}_{3} \mathrm{NO}_{2}$, albeit on a much longer time scale (ca. 1 week). In their ${ }^{1} \mathrm{H}$-NMR-spectra $\mathbf{2 b}, \mathbf{d}$ exhibit resonance signals of $N$-methyl and ferrocenylmethyl groups in a 2:1 integral ratio. All signals are shifted to a lower field with respect to the parent amine. This also holds for the ${ }^{13} \mathrm{C}-\mathrm{NMR}$ spectra with again the exception of the ipso carbon of the substituted ferrocenyl ring and, remarkably, the NMe groups for which, in turn, significant 
upfield shifts are observed (Table 1). In $\mathbf{2 b , d}$ the methyl and methylene carbons appear as singlets without any detectable coupling to nitrogen. The $\mathrm{NH}$ proton gives rise to a weak, rather broad signal in the ${ }^{1} \mathrm{H}-\mathrm{NMR}$ spectrum and a band at $3235 \mathrm{~cm}^{-1}$ in the IR $(\mathrm{KBr})$ spectrum. UV-vis spectra of $\mathbf{2} \mathbf{b}, \mathbf{d}$ are very similar to 1 a-d but with roughly only half the molar absorptivity.

Having identified both products we then found that these were present in basically equal amounts in each of the crude reaction mixtures obtained from $\mathrm{CH}_{2} \mathrm{Cl}_{2}$. This was further substantiated by following the conversion of ferrocenylmethyldimethylamine to $\mathbf{1 d}$ and the hydrochloride $\mathbf{2} \mathbf{d}$ by means of in situ NMR spectroscopy in $\mathrm{CD}_{2} \mathrm{Cl}_{2}$. Within $30 \mathrm{~min}$ the signals of the binuclear $\left(\mathrm{FCCH}_{2}\right)_{2} \mathrm{NMe}_{2}^{+}$ion were discernible and slowly increased in intensity. The progress of the reaction was accompanied by a continuous downfield shift of the signals pertinent to the starting material indicating the concomitant formation of its conjugate acid and the appearance of new signals in the aliphatic region of the ${ }^{1} \mathrm{H}$ - and ${ }^{13} \mathrm{C}-\mathrm{NMR}$ spectra. Two additional small triplet signals for the Cp-protons of a ring substituted ferrocene were observed at $\delta=4.77$ and $4.60 \mathrm{ppm}$ with a coupling constant of $1.96 \mathrm{~Hz}$ as well as a signal in the ${ }^{13} \mathrm{C}-\mathrm{NMR}$ at $\delta=70.4 \mathrm{ppm}$ which we tentatively attribute to the elusive chloromethylferrocene (vide infra). We also noted a distinct broadening of the methyl resonance of the $\mathrm{FcCH}_{2} \mathrm{NMe}_{2} / \mathrm{FcCH}_{2} \mathrm{NMe}_{2} \mathrm{H}^{+}$exchange signal, especially at some intermediate stage. This signal also appeared to be of larger intensity, as expected, and to be slightly shifted with respect to the pure compound. After about 3 days the reaction had gone to completion as indicated by the constant shift values and integral ratios of the individual components in the reaction mixture. 1d and $\mathbf{2 d}$ were indeed formed in essentially equimolar amounts.

Scheme 1 outlines an overall mechanism which is in accordance with all our observations. The initial, and obviously rate determining step $[3,6]$ is the nucleophilic attack of the amine on the electrophilic carbon atom of the $\mathrm{CH}_{2} \mathrm{Cl}_{2}$ solvent molecule which has been attributed a carbonyl like character [3]. This step, the so called Menschutkin reaction, has ample literature precedent $[2-5,14]$. Unlike any other case known to us, the resulting quaternary chloromethyldimethylammonium salt $\left[\mathrm{FcCH}_{2} \mathrm{NMe}_{2} \mathrm{CH}_{2} \mathrm{Cl}\right]^{+} \mathrm{Cl}^{-}$(A) is unstable and breaks down liberating chloromethylferrocene. Its subsequent reaction with a molecule of the starting material to give $1 \mathbf{a}-\mathbf{d}$ is also a key step of the original high yield synthesis of $\left(\mathrm{FcCH}_{2}\right)_{2} \mathrm{NMe}_{2}^{+} \mathrm{Br}^{-}$[11]. Let us now turn to the second fragment resulting from the decomposition of $\mathbf{A}$. From stoichiometry reasons we were soon pointed to $\mathrm{N}, \mathrm{N}$-dimethylchloromethyl amine which, according to the literature, is more adequately described as the iminium chloride $\mathrm{Me}_{2} \mathrm{~N}=\mathrm{CH}_{2}^{+} \mathrm{Cl}^{-}$[16-18]. If so, this compound must be acidic enough to protonate the starting material to its conjugate acid. The feasibility of this step was suggested to us by previous findings indicating that the iminium ion reacts with amines with a $\mathrm{p} K_{\mathrm{a}}$ smaller than 10.8 by deprotonation but usually adds to tertiary amines of lower basicity and low steric demand to give monoquaternary salts of monoalkylated aminals $\mathrm{Me}_{2} \mathrm{NCH}_{2} \mathrm{NR}_{3}^{+}$[19]. While ferrocenylmethyldimethylamine $\left(\mathrm{p} K_{\mathrm{a}}\right.$ in $\mathrm{H}_{2} \mathrm{O}=9.84$ [20], but note that the $\mathrm{p} K_{\mathrm{a}}$ in media of low dielectric constant may be significantly lower [21]) still lies below this limit, the formation of $\mathrm{FcCH}_{2} \mathrm{NMe}_{2} \mathrm{H}^{+}$presents clear evidence that in our case deprotonation occurs. Bis-( $N, N$-dimethylamino)methane, dimethylamine and 1,2-bis(dimethylamino)ethene have been identified as deprotonation products of the iminium salt [19] and this finally reminded us of the small additional signals in the aliphatic region that we had noted during our in situ NMR spectroscopic investigations.

In order to lend more credibility to this final reaction step and to positively identify the products arising from the proposed iminium intermediate we independently synthesized $\mathrm{Me}_{2} \mathrm{~N} \mathrm{CH}_{2}^{+} \mathrm{Cl}^{-}$and checked its reaction with equimolar amounts of $\mathrm{FcCH}_{2} \mathrm{NMe}_{2}$. Upon mixing, the iminium chloride which is only sparingly soluble in $\mathrm{CD}_{2} \mathrm{Cl}_{2}$ gradually dissolves, forming an orange suspension. At no time did the supernatant exhibit the characteristic low field ${ }^{1} \mathrm{H}$ and ${ }^{13} \mathrm{C}$ signals of the iminium ion $[18,19]$ and only the resonances of the $\mathrm{FcCH}_{2} \mathrm{NMe}_{2}$ / $\mathrm{FcCH}_{2} \mathrm{NMe}_{2} \mathrm{H}^{+}$couple and a small additional proton signal at $2.32 \mathrm{ppm}$, a region typical for aliphatic amines, were observed. When this reaction was monitored in $\mathrm{CD}_{3} \mathrm{CN}$ which dissolves the iminium salt, the low field signals of $\mathrm{Me}_{2} \mathrm{~N}=\mathrm{CH}_{2}^{+}$immediately disappeared upon addition of $\mathrm{FcCH}_{2} \mathrm{NMe}_{2}$. In $\mathrm{CD}_{2} \mathrm{Cl}_{2}$ the $\mathrm{NMe}$ groups of the equilibrated ferrocenylamine and its conjugate acid again appeared as a broad signal of higher intensity than expected by integration of the remaining signals. Furthermore, all resonances of the $\mathrm{FcCH}_{2} \mathrm{NMe}_{2} \mathrm{H}^{+}$salt in the fully equilibrated NMR sample were shifted slightly upfield with respect to those of pure isolated samples recorded under otherwise identical conditions. The ${ }^{13} \mathrm{C}$ NMR signals finally lead to the identification of $\operatorname{bis}(N, N$ dimethylamino)methane and dimethylamine in the reaction mixture [22]. The aminal gave somewhat broadened signals at $\delta=87.6$ and $44.3 \mathrm{ppm}$ for the methylene and $N$-methyl groups, respectively. Both are shifted downfield compared to those of an authentic sample. The broadening of all signals as well as the opposite direction of the shifts for the aminal and the $\mathrm{FcCH}_{2} \mathrm{NMe}_{2} \mathrm{H}^{+}$salt indicate that these components engage in an acid/base equilibrium as indicated in Eq. (1). This was indeed shown to be the case by NMR spectroscopy. Upon addition of increasing amounts of $\mathrm{Me}_{2} \mathrm{NCH}_{2} \mathrm{NMe}_{2}$ to a solution of $\mathrm{FcCH}_{2} \mathrm{NMe}_{2} \mathrm{H}^{+}$in $\mathrm{CD}_{2} \mathrm{Cl}_{2}$ all signals are shifted just in the manner indicated above.

When the reaction between equimolar amounts of 
$\mathrm{Me}_{2} \mathrm{~N}=\mathrm{CH}_{2}^{+} \mathrm{Cl}^{-}$and $\mathrm{FcCH}_{2} \mathrm{NMe}_{2}$ was investigated in more detail one further side process was uncovered. The orange solid obtained from treating the equilibrated mixture with $\mathrm{Et}_{2} \mathrm{O}$ consists of an approximately 20:1 mixture of $\mathrm{FcCH}_{2} \mathrm{NMe}_{2} \mathrm{H}^{+} \mathrm{Cl}^{-}$(2d) and $\left(\mathrm{FcCH}_{2}\right)_{2} \mathrm{NMe}_{2}^{+} \mathrm{Cl}^{-}$(1d). In the above NMR experiment, the signals of $\mathbf{1 d}$ are masked by the shifted, broadened signals of $\mathbf{2 d}$. To explain this finding one must additionally envoke the reaction outlined in Eq. (2). This side process must also be operative in the overall reaction of the parent amine with $\mathrm{CH}_{2} \mathrm{Cl}_{2}$ and is consequently added in Scheme 1. We could, however, obtain no firm evidence for the formation of bis(dimethylamino)ethene. If formed at all, it is most probably only a minor component [19] and may be obscured by other resonance signals.

$$
\begin{aligned}
& \mathrm{FcCH}_{2} \mathrm{NMe}_{2} \mathrm{H}^{+}+\mathrm{Me}_{2} \mathrm{NCH}_{2} \mathrm{NMe}_{2} \\
& \rightleftharpoons \mathrm{FcCH}_{2} \mathrm{NMe}_{2}+\mathrm{Me}_{2} \mathrm{NCH}_{2} \mathrm{NMe}_{2} \mathrm{H}^{+} \\
& \mathrm{NMe}_{2} \mathrm{CH}_{2}^{+}+2 \mathrm{FcCH}_{2} \mathrm{NMe}_{2} \\
& \rightarrow \mathrm{Me}_{2} \mathrm{NCH}_{2} \mathrm{NMe}_{2}+\left(\mathrm{FcCH}_{2}\right)_{2} \mathrm{NMe}_{2}^{+}
\end{aligned}
$$

Let us now discuss some of the more immediate implications of the overall conversion. First, regarding the reactions of similar amines with dihalomethane solvents, ferrocenylmethyldimethylamine sticks out as highly unusual in that its quaternary chloromethylammonium salt (intermediate $\mathbf{A}$ in Scheme 1) readily fragments into chloromethylferrocene, $\mathrm{FcCH}_{2} \mathrm{Cl}$, and $\mathrm{N}, \mathrm{N}$-dimethyliminium chloride, even under ambient conditions. In contrast, the corresponding trimethylammonium ion $\mathrm{FcCH}_{2} \mathrm{NMe}_{3}^{+}$is perfectly stable, its iodide being commercially available in large quantities. While this compound has evolved into a key synthon for the synthesis of substituted ferrocenes $\mathrm{FcCH}_{2} \mathrm{R}$ [23], it is revealing to note that the conditions required to substitute the $\mathrm{NMe}_{3}$ group are rather harsh compared to those applied in our case. Obviously the substitution of one proton by a chlorine atom is sufficient to destabilize the quaternary ammonium ion toward fragmentation. Both fragments may be regarded as rather high energy molecules. In fact, $\mathrm{FcCH}_{2} \mathrm{Cl}$ is a rather labile ferrocene derivative known as a source of the resonance stabilized ferrocenylmethylene cation $\mathrm{FcCH}_{2}^{+}$[24,25]. Its DielsAlder reaction with cyclopentadiene in $\mathrm{CH}_{2} \mathrm{Cl}_{2}$ at $78^{\circ} \mathrm{C}$ constitutes the most striking example for such a behavior [26] and implies that appreciable amounts of the ferrocenylmethylene cation are formed from $\mathrm{FcCH}_{2} \mathrm{Cl}$ even at low temperatures in low dielectricity media. The ferrocenylmethylene carbenium ion on the other hand is an extremely well investigated and easy to prepare species [27]. Its high intrinsic stability has been ascribed to resonance effects and the coordination of the exo double bond to the Fe nucleus in a fulvalenyl type structure [28].

\subsection{Attempted trapping of the $\mathrm{FcCH}_{2}^{+}$intermediate with other nucleophiles}

Having proposed the intermediacy of chloromethylferrocene (Scheme 1) we were now striving to trap this species with nucleophiles other than the parent amine. Attempts to employ $\mathrm{LiH}, \mathrm{NaBH}_{4}$ or $\mathrm{KCN}$ were, however, not met by success. Instead, $\left(\mathrm{FcCH}_{2}\right)_{2} \mathrm{NMe}_{2}^{+} \mathrm{Cl}^{-}$ (1d) and the hydrochloride $\mathbf{2 d}$ were isolated in good to excellent yields after chromatographic workup of the crude reaction mixtures. Since $\mathrm{CH}_{3} \mathrm{CN} / \mathrm{H}_{2} \mathrm{O}$ mixtures were employed as eluants the isolated samples of 1d all contain variable amounts of water as shown by a broad signal in the ${ }^{1} \mathrm{H}-\mathrm{NMR}$ at $\delta=2.20-2.25 \mathrm{ppm}$ and a broad, very intense, structured absorption band in the $3600-3300 \mathrm{~cm}^{-1}$ region in the IR spectra. Both are absent in water free samples of $\mathbf{1 d}$. Moreover, small shift differences as compared to water free samples are found in the NMR spectra (see Table 1). Thus, they are best formulated as $\mathbf{1 d} \cdot n \mathrm{H}_{2} \mathrm{O}$ with $n$ ranging from 1 to 3 . Orange-brown crystals grown from one of these samples were also investigated by X-ray analysis (vide infra). Remarkably, samples of $\mathbf{2 d}$ obtained by this protocol do not incorporate water. During workup, traces of a low polarity ferrocene derivative were noted in each case. They exhibit the same NMR signals as those found during our in situ experiments $\left({ }^{1} \mathrm{H}\right.$ : $\delta=4.78,4.63$ (each $\left.2 \mathrm{H},{ }^{3} J_{\mathrm{H}-\mathrm{H}}=1.96 \mathrm{~Hz}\right), 4.28\left(\mathrm{~s}, 7 \mathrm{H}, \mathrm{Cp}\right.$ and $\left.\mathrm{CH}_{2}\right) ;{ }^{13} \mathrm{C}$ : 75.4, 74.1, $70.4\left(\mathrm{C}_{i p s o}, \mathrm{C}_{\alpha, \beta}\right.$ of the substituted $\mathrm{Cp}$-ring), $\left.70.5\left(\mathrm{Cp}_{\text {unsubst. }}\right)\right)$ but the low yields and our inability to crystallize the oily residue precluded their firm identification. We nevertheless believe that these samples are $\mathrm{FcCH}_{2} \mathrm{Cl}$. Our failure to isolate $\mathrm{FcCH}_{2} \mathrm{X}(\mathrm{X}=\mathrm{H}, \mathrm{CN})$ from these reactions may be due to either the rather limited solubility of the applied nucleophile salts in $\mathrm{CH}_{2} \mathrm{Cl}_{2}$ and/or the higher nucleophilicity of the parent amine.

We therefore decided to react $\mathrm{FcCH}_{2} \mathrm{NMe}_{2}$ with $\mathrm{CH}_{2} \mathrm{Cl}_{2}$ in the presence of a 15 -fold excess of $\mathrm{NEt}_{3}$. This amine reportedly does not react with $\mathrm{CH}_{2} \mathrm{Cl}_{2}$ to an appreciable extent during the typical time scale of our experiments [3] but is still a potent nucleophile. Thus, it may serve as both a trapping reagent and a base [19], capturing the proton from $\mathrm{NMe}_{2} \mathrm{CH}_{2}^{+} \mathrm{Cl}^{-}$liberated upon the fragmentation of $\mathrm{A}$. Indeed, $\mathrm{FcCH}_{2} \mathrm{NEt}_{3}^{+} \mathrm{SbF}_{6}^{-}$ (3) was formed beside roughly equal amounts of $\mathbf{1 b}$ in such a competition experiment, further supporting the mechanism depicted in Scheme 1. Attempts to separate 1b and 3 by column chromatography or fractional crystallization were unsuccessful but the spectroscopic data of 3 could nevertheless be established (Table 1).

\subsection{A non-toxic, high-yield route to $\left(\mathrm{FCCH}_{2}\right)_{2} \mathrm{NMe}_{2}^{+} \mathrm{Cl}^{-}(\mathbf{I d})$}

The reactivity of $\mathrm{FcCH}_{2} \mathrm{NMe}_{2}$ toward $\mathrm{CH}_{2} \mathrm{Cl}_{2}$ is very 
reminiscent of the von Braun cleavage reaction, which, however, utilizes a much stronger electron acceptor (i.e. the $\mathrm{CN}$ group) than the chloromethyl moiety. The ease of fragmentation of intermediate A suggested to us that a similar reaction might be induced by treating $\mathrm{FcCH}_{2} \mathrm{NMe}_{2}$ with a more powerful electrophile than $\mathrm{CH}_{2} \mathrm{Cl}$. If chosen properly, such a reaction would then provide an alternative, high-yield route to the binuclear $\left(\mathrm{FcCH}_{2}\right)_{2} \mathrm{NMe}_{2}^{+} \mathrm{Cl}^{-}$(1d) without the necessity to employ the toxic $\mathrm{BrCN}$ [11], or sacrificing one third of the starting material with the additional hazzle to separate 1d from equimolar amounts of the hydrochloride 2d.

In general, the conversion of aliphatic tertiary amines to alkyl halides (halo-de-amination) may be effected by either the von Braun cleavage reaction [29,30], by treating tertiary amines with phosgene [31] or certain chloroformates ROCOCl $([30,34]$ or upon heating the halogenides (preferably the iodides) of quaternary ammonium salts [35]). The acyl substituent, on the other hand, is generally too weak an electron acceptor to induce the de-amination of quaternary salts $\mathrm{R}_{3} \mathrm{NCOR}^{\prime+}$. One exception are aminals which are readily cleaved by acetyl chloride [17-19]. This reaction provides the perhaps most general and easiest access to iminium salts (Eq. (3)). Since $\mathrm{FcCH}_{2}^{+}$and $\mathrm{Me}_{2} \mathrm{~N}=\mathrm{CH}_{2}^{+}$ are liberated from $\mathrm{FcCH}_{2} \mathrm{NMe}_{2} \mathrm{CH}_{2} \mathrm{Cl}^{+}$with exceptional ease, we hoped that ferrocenylmethyldimethylamine might parallel the high reactivity of aminals. As outlined in Eq. (4) our expectations were indeed met by success. Upon simply adding half an equivalent of acetyl chloride dissolved in $\mathrm{Et}_{2} \mathrm{O}$ to a suspension of $\mathrm{FCCH}_{2} \mathrm{NMe}_{2}$ in the same solvent, the dinuclear 1d was obtained as an analytically pure orange precipitate. The ready availability of acetyl chloride and its non-toxicity constitute a major advantage over the original route while providing the same high yield [11].

Table 2

Bond distances and selected bond angles for $\mathrm{FcCH}_{2} \mathrm{NMe}_{2} \mathrm{H}^{+} \mathrm{Cl}^{-}$ (2d)

\begin{tabular}{lrlr}
\hline $\mathrm{Fe}(1)-\mathrm{C}(1)$ & $2.033(2)$ & $\mathrm{C}(1)-\mathrm{C}(2)$ & $1.434(2)$ \\
$\mathrm{Fe}(1)-\mathrm{C}(2)$ & $2.046(2)$ & $\mathrm{C}(2)-\mathrm{C}(3)$ & $1.427(2)$ \\
$\mathrm{Fe}(1)-\mathrm{C}(3)$ & $2.050(2)$ & $\mathrm{C}(3)-\mathrm{C}(4)$ & $1.424(2)$ \\
$\mathrm{Fe}(1)-\mathrm{C}(4)$ & $2.051(2)$ & $\mathrm{C}(4)-\mathrm{C}(5)$ & $1.425(2)$ \\
$\mathrm{Fe}(1)-\mathrm{C}(5)$ & $2.040(2)$ & $\mathrm{C}(1)-\mathrm{C}(5)$ & $1.431(2)$ \\
$\mathrm{Fe}(1)-\mathrm{C}(6)$ & $2.045(2)$ & $\mathrm{C}(6)-\mathrm{C}(7)$ & $1.425(4)$ \\
$\mathrm{Fe}(1)-\mathrm{C}(7)$ & $2.036(2)$ & $\mathrm{C}(7)-\mathrm{C}(8)$ & $1.409(4)$ \\
$\mathrm{Fe}(1)-\mathrm{C}(8)$ & $2.050(2)$ & $\mathrm{C}(8)-\mathrm{C}(9)$ & $1.406(3)$ \\
$\mathrm{Fe}(1)-\mathrm{C}(9)$ & $2.045(2)$ & $\mathrm{C}(9)-\mathrm{C}(10)$ & $1.408(3)$ \\
$\mathrm{Fe}(1)-\mathrm{C}(10)$ & $2.035(2)$ & $\mathrm{C}(6)-\mathrm{C}(10)$ & $1.424(3)$ \\
$\mathrm{C}(1)-\mathrm{C}(11)$ & $1.492(2)$ & $\mathrm{N}(1)-\mathrm{C}(12)$ & $1.486(2)$ \\
$\mathrm{N}(1)-\mathrm{C}(11)$ & $1.503(2)$ & $\mathrm{N}(1)-\mathrm{C}(13)$ & $1.485(2)$ \\
$\mathrm{C}(12)-\mathrm{N}(1)-\mathrm{C}(11)$ & $109.81(12)$ & $\mathrm{C}(12)-\mathrm{N}(1)-\mathrm{C}(13)$ & $110.9(2)$ \\
$\mathrm{C}(13)-\mathrm{N}(1)-\mathrm{C}(11)$ & $112.77(13)$ & $\mathrm{C}(1)-\mathrm{C}(11)-\mathrm{N}(1)$ & $113.18(12)$ \\
& & & \\
\hline
\end{tabular}

$\mathrm{Me}_{2} \mathrm{NCH}_{2} \mathrm{NMe}_{2}+\mathrm{CH}_{3} \mathrm{COCl}$

$\rightarrow \mathrm{Me}_{2} \mathrm{NCH}_{2}^{+} \mathrm{Cl}^{-}+\mathrm{CH}_{3} \mathrm{CONMe}_{2}$

$2 \mathrm{FcCH}_{2} \mathrm{NMe}_{2}+\mathrm{CH}_{3} \mathrm{COCl}$

$\rightarrow\left(\mathrm{FcCH}_{2}\right)_{2} \mathrm{NMe}_{2}^{+} \mathrm{Cl}^{-}+\mathrm{CH}_{3} \mathrm{CONMe}_{2}$

\subsection{X-ray structural studies of $\mathrm{FcCH}_{2} \mathrm{NMe}_{2} \mathrm{H}^{+}$ $\mathrm{Cl}^{-}(\mathbf{2 d}),\left(\mathrm{FcCH}_{2}\right)_{2} \mathrm{NMe}_{2}^{+} \mathrm{SbF}_{6}^{-}$(1b) and $\left(\mathrm{FcCH}_{2}\right)_{2} \mathrm{NMe}_{2}^{+} \mathrm{Cl}^{-}$(1d)}

The bis(ferrocenyl-methyl)dimethyl ammonium salts $\mathbf{1 b}$ and $\mathbf{1 d}$ and the mononuclear hydrochloride $\mathbf{2 d}$ were investigated by X-ray structure analysis. Tables 2 and 3 list the bond lengths and relevant bond angles while fractional atomic coordinates and $U_{\text {eq }}$ are provided in Tables S1-S3 in the Supporting Information. ORTEP plots of the respective cations are depicted in Figs. 1-3. The molecular structure of the $\mathrm{FcCH}_{2} \mathrm{NMe}_{2} \mathrm{H}^{+}$cation in the chloride salt $\mathbf{2 d}$ is very similar to that observed in either its tetrachlorozincate [39] or $\mathrm{B}_{12} \mathrm{H}_{12}$ borane cluster salt [40] and also resembles that of the $\mathrm{FcCH}_{2} \mathrm{NMe}_{3}^{+}$[41-43] and $\mathrm{FcCH}_{2} \mathrm{NMe}_{2} \mathrm{Et}^{+}$cations [44]. As usually found for ferrocene derivatives, the two carbocyclic ligands are planar and parallel and exhibit a close to eccliptic conformation (Table 4). The short $\mathrm{NH} \cdots \mathrm{Cl}$ distance of $2.18 \AA$ suggests the presence of a rather strong $\mathrm{H}$-bridge and compares well to the $2.13 \AA$ found for $\mathrm{NH} \cdots \mathrm{O}$ contacts to perchlorate in a ferrocene with an appended protonated oxoaza crown ether [45]. It is much shorter than the $3.11 \AA$ observed in the tetrachlorozincate salt, where the chloride is part of a complex counterion and additional hydrogen bonding to cocrystallized water exists $\left(d_{\mathrm{NH} \cdots \mathrm{O}}=2.76 \AA\right)$ [39]. Besides this structural evidence, the relevance of the $\mathrm{NH}{ }^{\cdots} \mathrm{Cl}$ interaction in $\mathrm{FcCH}_{2} \mathrm{NMe}_{2} \mathrm{H}^{+} \mathrm{Cl}^{-}$(2d) is demonstrated by a broad, intense and richly structured band in the IR that stretches from 2650 to $2350 \mathrm{~cm}^{-1}$. This band is shifted to lower energies by a considerable amount as compared to the analogous $\mathrm{SbF}_{6}^{-}$salt $\mathbf{2 b}$ where a much weaker and sharper absorption band at $3235 \mathrm{~cm}^{-1}$ is found instead.

Both, the $\mathrm{SbF}_{6}^{-}$and the $\mathrm{Cl}^{-}$salts of $\left(\mathrm{FcCH}_{2}\right)_{2} \mathrm{NMe}_{2}^{+}$cocrystallize with solvent molecules. In $\mathbf{1 b}$ one rotationally disordered molecule of chlorobenzene is found for each cation. $1 d \cdot 4 / 3 \mathrm{H}_{2} \mathrm{O}$ contains pairs of three different cation conformers $(Z=6)$ and eight molecules of water in the unit cell. The four different $\left(\mathrm{FcCH}_{2}\right)_{2} \mathrm{NMe}_{2}^{+}$cations in the structures of $\mathbf{1 b}$ and $\mathbf{1 d} \cdot 4 / 3 \mathrm{H}_{2} \mathrm{O}$ are rather similar. Relevant structural data are combined in Table 4 such that related bond parameters appear in the same row. Each of the cations display a cisoid arrangement of the two ferrocenyl subunits. The main differences originate from the interplanar angles between the substituted cyclopentadienyl ligands $\left(\mathrm{Cp}^{\mathrm{R}}\right)$ on adjacent $\mathrm{Fe}$ atoms., 
Table 3

Bond distances and selected bond angles for the $\left(\mathrm{FcCH}_{2}\right)_{2} \mathrm{NMe}_{2}^{+}$cations in the $\mathrm{SbF}_{6}^{-}$salt $\mathbf{1 b}$ and the $\mathrm{Cl}^{-}$salt $\mathbf{1 d} \cdot 4 / 3 \mathrm{H}_{2} \mathrm{O}(3$ independent cations)

\begin{tabular}{|c|c|c|c|c|c|c|c|}
\hline $1 \mathrm{~b}$ & & 1d (cation 1) & & 1d (cation 2) & & Id (cation 3) & \\
\hline $\mathrm{Fe}(1)-\mathrm{C}(11)$ & $2.024(6)$ & $\mathrm{Fe}(1)-\mathrm{C}(11)$ & $2.045(5)$ & $\mathrm{Fe}(3)-\mathrm{C}(21)$ & $2.037(4)$ & $\mathrm{Fe}(5)-\mathrm{C}(31)$ & $2.044(5)$ \\
\hline $\mathrm{Fe}(1)-\mathrm{C}(12)$ & $2.029(6)$ & $\mathrm{Fe}(1)-\mathrm{C}(12)$ & $2.038(5)$ & $\mathrm{Fe}(3)-\mathrm{C}(22)$ & $2.036(5)$ & $\mathrm{Fe}(5)-\mathrm{C}(32)$ & $2.037(5)$ \\
\hline $\mathrm{Fe}(1)-\mathrm{C}(13)$ & $2.045(7)$ & $\mathrm{Fe}(1)-\mathrm{C}(13)$ & $2.045(5)$ & $\mathrm{Fe}(3)-\mathrm{C}(23)$ & $2.040(5)$ & $\mathrm{Fe}(5)-\mathrm{C}(33)$ & $2.040(5)$ \\
\hline $\mathrm{Fe}(1)-\mathrm{C}(14)$ & $2.051(8)$ & $\mathrm{Fe}(1)-\mathrm{C}(14)$ & $2.024(5)$ & $\mathrm{Fe}(3)-\mathrm{C}(24)$ & $2.040(4)$ & $\mathrm{Fe}(5)-\mathrm{C}(34)$ & $2.045(5)$ \\
\hline $\mathrm{Fe}(1)-\mathrm{C}(15)$ & $2.045(7)$ & $\mathrm{Fe}(1)-\mathrm{C}(15)$ & $2.036(5)$ & $\mathrm{Fe}(3)-\mathrm{C}(25)$ & $2.035(4)$ & $\mathrm{Fe}(5)-\mathrm{C}(35)$ & $2.040(5)$ \\
\hline $\mathrm{Fe}(1)-\mathrm{C}(31)$ & $2.047(8)$ & $\mathrm{Fe}(1)-\mathrm{C}(16)$ & $2.040(4)$ & $\mathrm{Fe}(3)-\mathrm{C}(26)$ & $2.023(4)$ & $\mathrm{Fe}(5)-\mathrm{C}(36)$ & $2.045(4)$ \\
\hline $\mathrm{Fe}(1)-\mathrm{C}(33)$ & $2.014(8)$ & $\mathrm{Fe}(1)-\mathrm{C}(18)$ & $2.046(5)$ & $\mathrm{Fe}(3)-\mathrm{C}(28)$ & $2.036(4)$ & $\mathrm{Fe}(5)-\mathrm{C}(38)$ & $2.045(5)$ \\
\hline $\mathrm{Fe}(1)-\mathrm{C}(34)$ & $2.023(8)$ & $\mathrm{Fe}(1)-\mathrm{C}(19)$ & $2.026(4)$ & $\mathrm{Fe}(3)-\mathrm{C}(29)$ & $2.043(4)$ & $\mathrm{Fe}(5)-\mathrm{C}(39)$ & $2.033(4)$ \\
\hline $\mathrm{Fe}(1)-\mathrm{C}(35)$ & $2.039(7)$ & $\mathrm{Fe}(1)-\mathrm{C}(110)$ & $2.019(5)$ & $\mathrm{Fe}(3)-\mathrm{C}(210)$ & $2.028(4)$ & $\mathrm{Fe}(5)-\mathrm{C}(310)$ & $2.027(4)$ \\
\hline $\mathrm{Fe}(2)-\mathrm{C}(21)$ & $2.030(6)$ & $\mathrm{Fe}(2)-\mathrm{C}(115)$ & $2.031(5)$ & $\mathrm{Fe}(4)-\mathrm{C}(215)$ & $2.026(4)$ & $\mathrm{Fe}(6)-\mathrm{C}(315)$ & $2.017(4)$ \\
\hline $\mathrm{Fe}(2)-\mathrm{C}(22)$ & $2.040(7)$ & $\mathrm{Fe}(2)-\mathrm{C}(116)$ & $2.032(5)$ & $\mathrm{Fe}(4)-\mathrm{C}(216)$ & $2.026(4)$ & $\mathrm{Fe}(6)-\mathrm{C}(316)$ & $2.024(5)$ \\
\hline $\mathrm{Fe}(2)-\mathrm{C}(23)$ & $2.043(8)$ & $\mathrm{Fe}(2)-\mathrm{C}(117)$ & $2.041(5)$ & $\mathrm{Fe}(4)-\mathrm{C}(217)$ & $2.040(4)$ & $\mathrm{Fe}(6)-\mathrm{C}(317)$ & $2.047(5)$ \\
\hline $\mathrm{Fe}(2)-\mathrm{C}(24)$ & $2.059(8)$ & $\mathrm{Fe}(2)-\mathrm{C}(118)$ & $2.034(5)$ & $\mathrm{Fe}(4)-\mathrm{C}(218)$ & $2.049(5)$ & $\mathrm{Fe}(6)-\mathrm{C}(318)$ & $2.043(5)$ \\
\hline $\mathrm{Fe}(2)-\mathrm{C}(41)$ & $2.041(9)$ & $\mathrm{Fe}(2)-\mathrm{C}(120)$ & $2.024(5)$ & $\mathrm{Fe}(4)-\mathrm{C}(220)$ & $2.026(5)$ & $\mathrm{Fe}(6)-\mathrm{C}(320)$ & $2.032(5)$ \\
\hline $\mathrm{Fe}(2)-\mathrm{C}(42)$ & $2.035(8)$ & $\mathrm{Fe}(2)-\mathrm{C}(121)$ & $2.032(5)$ & $\mathrm{Fe}(4)-\mathrm{C}(221)$ & $2.026(5)$ & $\mathrm{Fe}(6)-\mathrm{C}(321)$ & $2.044(5)$ \\
\hline $\mathrm{Fe}(2)-\mathrm{C}(43)$ & $2.052(8)$ & $\mathrm{Fe}(2)-\mathrm{C}(122)$ & $2.039(5)$ & $\mathrm{Fe}(4)-\mathrm{C}(222)$ & $2.037(6)$ & $\mathrm{Fe}(6)-\mathrm{C}(322)$ & $2.039(5)$ \\
\hline $\mathrm{Fe}(2)-\mathrm{C}(44)$ & $2.039(8)$ & $\mathrm{Fe}(2)-\mathrm{C}(123)$ & $2.052(6)$ & $\mathrm{Fe}(4)-\mathrm{C}(223)$ & $2.036(6)$ & $\mathrm{Fe}(6)-\mathrm{C}(323)$ & $2.023(6)$ \\
\hline $\mathrm{Fe}(2)-\mathrm{C}(45)$ & $2.031(9)$ & $\mathrm{Fe}(2)-\mathrm{C}(124)$ & $2.034(5)$ & $\mathrm{Fe}(4)-\mathrm{C}(224)$ & $2.042(5)$ & $\mathrm{Fe}(6)-\mathrm{C}(324)$ & $2.031(6)$ \\
\hline$C(31)-C(32)$ & $1.357(13)$ & $C(11)-C(12)$ & $1.398(9)$ & $\mathrm{C}(21)-\mathrm{C}(22)$ & $1.427(7)$ & $\mathrm{C}(31)-\mathrm{C}(32)$ & $1.424(7)$ \\
\hline$C(32)-C(33)$ & $1.411(16)$ & $\mathrm{C}(12)-\mathrm{C}(13)$ & $1.419(7)$ & $\mathrm{C}(22)-\mathrm{C}(23)$ & $1.415(7)$ & $\mathrm{C}(32)-\mathrm{C}(33)$ & $1.418(7)$ \\
\hline $\mathrm{C}(33)-\mathrm{C}(34)$ & $1.426(16)$ & $C(13)-C(14)$ & $1.403(9)$ & $\mathrm{C}(23)-\mathrm{C}(24)$ & $1.419(7)$ & $C(33)-C(34)$ & $1.399(8)$ \\
\hline$C(33)-C(34)$ & $1.426(16)$ & $C(14)-C(15)$ & $1.419(10)$ & $\mathrm{C}(24)-\mathrm{C}(25)$ & $1.419(7)$ & $C(34)-C(35)$ & $1.428(8)$ \\
\hline$C(34)-C(35)$ & $1.349(14)$ & $C(11)-C(15)$ & $1.410(9)$ & $\mathrm{C}(21)-\mathrm{C}(25)$ & $1.422(7)$ & $\mathrm{C}(31)-\mathrm{C}(35)$ & $1.404(8)$ \\
\hline$C(11)-C(12)$ & $1.421(9)$ & $C(16)-C(17)$ & $1.419(7)$ & $C(26)-C(27)$ & $1.398(7)$ & $C(36)-C(37)$ & $1.409(6)$ \\
\hline$C(12)-C(13)$ & $1.411(11)$ & $\mathrm{C}(17)-\mathrm{C}(18)$ & $1.413(7)$ & $\mathrm{C}(27)-\mathrm{C}(28)$ & $1.420(7)$ & $\mathrm{C}(37)-\mathrm{C}(38)$ & $1.414(7)$ \\
\hline$C(13)-C(14)$ & $1.430(13)$ & $\mathrm{C}(18)-\mathrm{C}(19)$ & $1.438(7)$ & $\mathrm{C}(28)-\mathrm{C}(29)$ & $1.418(7)$ & $\mathrm{C}(38)-\mathrm{C}(39)$ & $1.419(7)$ \\
\hline$C(14)-C(15)$ & $1.414(11)$ & $\mathrm{C}(19)-\mathrm{C}(110)$ & $1.424(6)$ & $\mathrm{C}(29)-\mathrm{C}(210)$ & $1.434(6)$ & $\mathrm{C}(39)-\mathrm{C}(310)$ & $1.430(6)$ \\
\hline$C(11)-C(15)$ & $1.429(9)$ & $C(16)-C(110)$ & $1.429(6)$ & $C(26)-C(210)$ & $1.438(6)$ & $C(36)-C(310$ & $1.430(6)$ \\
\hline$C(21)-C(22)$ & $1.437(9)$ & $\mathrm{C}(115)-\mathrm{C}(116)$ & $1.433(7)$ & $C(215)-C(216)$ & $1.428(6)$ & $C(315)-C(316)$ & $1.421(7)$ \\
\hline$C(23)-C(24)$ & $1.398(14)$ & $\mathrm{C}(118)-\mathrm{C}(119)$ & $1.413(7)$ & $\mathrm{C}(218)-\mathrm{C}(219)$ & $1.412(7)$ & $\mathrm{C}(318)-\mathrm{C}(319)$ & $1.411(8)$ \\
\hline$C(24)-C(25)$ & $1.424(12)$ & $C(115)-C(119)$ & $1.430(6)$ & $\mathrm{C}(215)-\mathrm{C}(219)$ & $1.439(6)$ & $C(315)-C(319)$ & $1.431(6)$ \\
\hline$C(41)-C(42)$ & $1.392(15)$ & $C(120)-C(121)$ & $1.485(9)$ & $\mathrm{C}(220)-\mathrm{C}(221)$ & $1.396(8)$ & $C(320)-C(321)$ & $1.389(8)$ \\
\hline$C(42)-C(43)$ & $1.374(14)$ & $C(121)-C(122)$ & $1.400(8)$ & $\mathrm{C}(221)-\mathrm{C}(222)$ & $1.409(9)$ & $C(321)-C(322)$ & $1.401(8)$ \\
\hline$C(43)-C(44)$ & $1.397(12)$ & $C(122)-C(123)$ & $1.376(8)$ & $\mathrm{C}(222)-\mathrm{C}(223)$ & $1.351(10)$ & $C(322)-C(323)$ & $1.372(10)$ \\
\hline$C(44)-C(45)$ & $1.394(14)$ & $C(123)-C(124)$ & $1.360(9)$ & $C(223)-C(224)$ & $1.416(9)$ & $C(323)-C(324)$ & $1.422(10)$ \\
\hline$C(41)-C(45)$ & $1.407(13)$ & $\mathrm{C}(120)-\mathrm{C}(124)$ & $1.396(9)$ & $\mathrm{C}(220)-\mathrm{C}(224)$ & $1.433(8)$ & $\mathrm{C}(320)-\mathrm{C}(324)$ & $1.423(9)$ \\
\hline$C(1)-C(11)$ & $1.498(8)$ & $C(110)-C(111)$ & $1.491(6)$ & $\mathrm{C}(210)-\mathrm{C}(211)$ & $1.481(6)$ & $C(310)-C(311)$ & $1.480(6)$ \\
\hline$C(2)-C(21)$ & $1.476(8)$ & $C(114)-C(115)$ & $1.483(6)$ & $\mathrm{C}(214)-\mathrm{C}(215)$ & $1.499(6)$ & $C(314)-C(315)$ & $1.487(6)$ \\
\hline$N(1)-C(1)$ & $1.521(7)$ & $N(1)-C(111)$ & $1.523(5)$ & $N(2)-C(211)$ & $1.531(5)$ & $N(3)-C(311)$ & $1.531(5)$ \\
\hline$N(1)-C(2)$ & $1.534(8)$ & $N(1)-C(114)$ & $1.532(5)$ & $N(2)-C(214)$ & $1.523(5)$ & $N(3)-C(314)$ & $1.528(5)$ \\
\hline$N(1)-C(3)$ & $1.511(7)$ & $N(1)-C(112)$ & $1.491(5)$ & $N(2)-C(212)$ & $1.491(5)$ & $N(3)-C(312)$ & $1.500(5)$ \\
\hline$N(1)-C(4)$ & $1.509(7)$ & $N(1)-C(113)$ & $1.491(5)$ & $N(2)-C(213)$ & $1.494(5)$ & $N(3)-C(313)$ & $1.489(5)$ \\
\hline$C(1)-N(1)-C(2)$ & $107.7(4)$ & $\mathrm{C}(111)-\mathrm{N}(1)-\mathrm{C}(114)$ & $107.1(3)$ & $\mathrm{C}(214)-\mathrm{N}(2)-\mathrm{C}(211)$ & $108.2(3)$ & $\mathrm{C}(314)-\mathrm{N}(3)-\mathrm{C}(311)$ & $107.9(3)$ \\
\hline$C(3)-N(1)-C(1)$ & $110.2(5)$ & $\mathrm{C}(112)-\mathrm{N}(1)-\mathrm{C}(111)$ & $110.7(3)$ & $\mathrm{C}(212)-\mathrm{N}(2)-\mathrm{C}(211)$ & $109.6(3)$ & $\mathrm{C}(312)-\mathrm{N}(3)-\mathrm{C}(311)$ & $110.7(3)$ \\
\hline$C(4)-N(1)-C(1)$ & $110.2(5)$ & $\mathrm{C}(113)-\mathrm{N}(1)-\mathrm{C}(111)$ & 109.7(3) & $\mathrm{C}(213)-\mathrm{N}(2)-\mathrm{C}(211)$ & $109.6(3)$ & $C(313)-N(3)-C(311)$ & $108.8(3)$ \\
\hline$C(4)-N(1)-C(2)$ & $108.7(5)$ & $\mathrm{C}(112)-\mathrm{N}(1)-\mathrm{C}(114)$ & $109.9(3)$ & $\mathrm{C}(212)-\mathrm{N}(2)-\mathrm{C}(214)$ & $109.1(3)$ & $\mathrm{C}(312)-\mathrm{N}(3)-\mathrm{C}(314)$ & $109.4(3)$ \\
\hline$C(3)-N(1)-C(2)$ & $109.6(5)$ & $\mathrm{C}(113)-\mathrm{N}(1)-\mathrm{C}(112)$ & $109.4(3)$ & $\mathrm{C}(213)-\mathrm{N}(2)-\mathrm{C}(214)$ & $110.3(3)$ & $\mathrm{C}(313)-\mathrm{N}(3)-\mathrm{C}(314)$ & $110.5(3)$ \\
\hline $\mathrm{C}(11)-\mathrm{C}(1)-\mathrm{N}(1)$ & $113.9(4)$ & $\mathrm{C}(110)-\mathrm{C}(111)-\mathrm{N}(1)$ & $115.6(3)$ & $C(210)-C(211)-N(2)$ & $111.8(3)$ & $\mathrm{C}(310)-\mathrm{C}(311)-\mathrm{N}(3)$ & $112.6(3)$ \\
\hline $\mathrm{C}(21)-\mathrm{C}(2)-\mathrm{N}(1)$ & $113.8(5)$ & $\mathrm{C}(115)-\mathrm{C}(114)-\mathrm{N}(1)$ & $115.1(3)$ & $\mathrm{C}(215)-\mathrm{C}(214)-\mathrm{N}(2)$ & $113.0(3)$ & $\mathrm{C}(315)-\mathrm{C}(314)-\mathrm{N}(3)$ & $113.2(3)$ \\
\hline
\end{tabular}




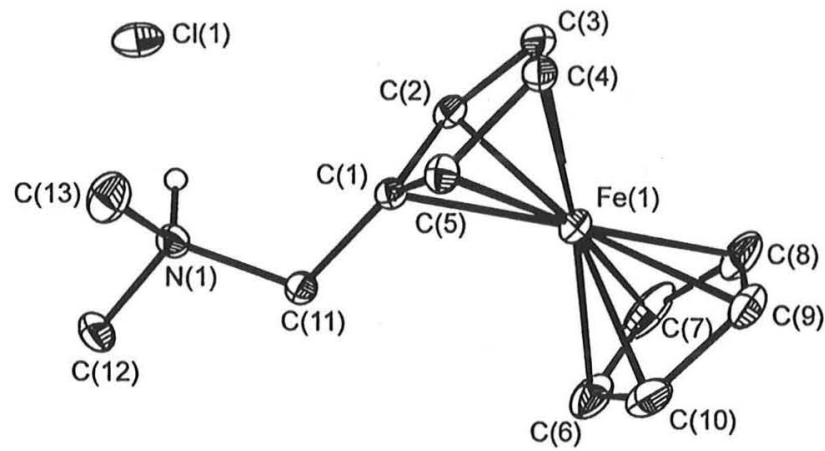

Fig. 1. ORTEP drawing of complex 2a. All hydrogens but the one attached to $\mathrm{N}(1)$ are omitted. Thermal ellipsoids are shown on a $30 \%$ probability level.

the rotational angles between the two ring ligands coordinated to the same Fe atom and the dihedral angles as defined by the two axes Fe-centroid of the respective $\mathrm{Cp}^{\mathrm{R}}$ and a line connecting these centroids (Table 4). The scatter of individual values suggests a fair amount of conformational flexibility within the binuclear cations. In all four cases the Fe atom binds somewhat asymmetrically to the two different carbocyclic ligands. While the mean $\mathrm{Fe}-\mathrm{C}$ distances are almost identical for the substituted and the unsubstituted rings, the substituted ring ligand is slightly expanded and possesses the larger intraring $\mathrm{C}-\mathrm{C}$ bond distances. This draws the less electron rich $\mathrm{Cp}^{\mathrm{R}}$ ligand closer to the metal (Table 4). A closer inspection of the data available for similar systems [39-42] reveals the same overall picture which seems to be of more general validity.

In the chloride salt $\mathbf{1 d} \cdot 4 / 3 \mathrm{H}_{2} \mathrm{O}$ hydrophilic domains exist. They are formed by water molecules that are hydrogen bonded to the $\mathrm{Cl}^{-}$counterions with $\mathrm{Cl} \cdots \mathrm{O}$ distances ranging from 3.19 to $3.29 \AA$. $\mathrm{Cl}(1)$ and $\mathrm{Cl}(2)$ form short contacts to three water molecules whereas $\mathrm{Cl}(3)$ is bonded to $\mathrm{O}(4)$ only. Due to the statistical replacement of $\mathrm{Cl}(3)$ by $\mathrm{CN}^{-}$and the cyanide nitrogen being disordered there are, however, some uncertainties in the structure pertaining to the vicinity of $\mathrm{O}(4)$. The $\left(\mathrm{H}_{2} \mathrm{O}\right)_{4}(\mathrm{Cl})_{3}$ entities are linked via shorter $\mathrm{O}(4) \cdots \mathrm{O}(2)$ hydrogen bridges of $2.94 \AA$ to one dimensional infinite chains that run parallel the $a$ axis. One isolated chain is

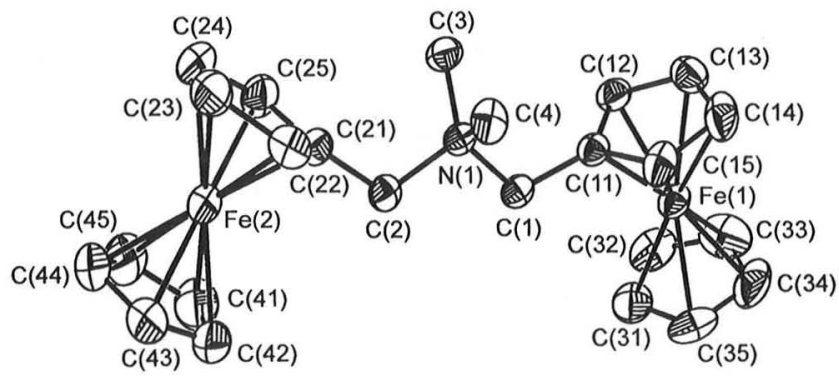

Fig. 2. ORTEP drawing of the cation $\left(\mathrm{FcCH}_{2}\right)_{2} \mathrm{NMe}_{2}^{+}$in the $\mathrm{SbF}_{6}^{-}$ salt 1b with $30 \%$ thermal ellipsoids. Hydrogen atoms are omitted.

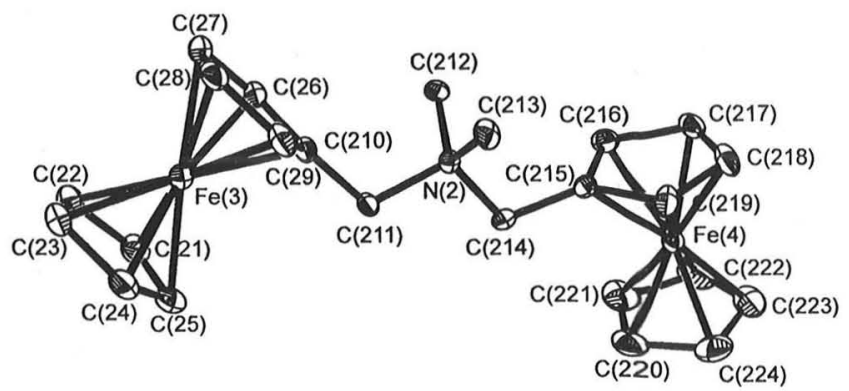

Fig. 3. ORTEP drawing of one of the three independent cations of $\left(\mathrm{FcCH}_{2}\right)_{2} \mathrm{NMe}_{2}^{+}$in the $\mathrm{Cl}^{-}$salt $1 \mathrm{~d} \cdot 4 / 3 \mathrm{H}_{2} \mathrm{O}$ (cation 2) with $30 \%$ thermal ellipsoids. Hydrogen atoms are omitted.

depicted in Fig. 4a. As shown in the packing diagram in Fig. $4 b$, the chains occupy channels that penetrate the cation sublattice. Contacts between the hydrophilic chains and the mostly hydrophobic cations are made via the roughly tetrahedral $\mathrm{N}\left(\mathrm{CH}_{3}\right)_{2}\left(\mathrm{CH}_{2} \mathrm{R}\right)_{2}^{+}$subunits with the $\mathrm{Cl}^{-}$ions pointing toward two $(\mathrm{Cl}(1), \mathrm{Cl}(2))$ or three (Cl(3)) triangular faces of the $\mathrm{NR}_{4}^{+}$units of neighboring cations. Again, the presence of such interactions is indicated by an intense structured $\mathrm{OH}$ band centered at $3450 \mathrm{~cm}^{-1}$ in the IR. It has already been suggested that hydrogen bridging between the methylene or methyl groups bound to a quaternary nitrogen and the counterion plays a certain role in such structures $[39,42]$. The shortest contacts $\mathrm{CH} \cdots \mathrm{X}\left(\mathrm{X}=\mathrm{F}\right.$ in $\mathrm{SbF}_{6}^{-}$or $\left.\mathrm{Cl}^{-}\right)$are 3.33 and $3.48 \AA$ for methylene and $3.19 \AA$ for methyl groups in $\mathbf{1 b}$ and 3.59 and $3.75 \AA$, respectively, for the methylene carbons in $\mathbf{1 d}$. These values are in the same range as those found for the $\mathrm{ZnCl}_{4}^{2-}$ salt of $\mathrm{FcCH}_{2} \mathrm{NMe}_{2} \mathrm{H}^{+} \quad(\mathrm{CH} \cdots \mathrm{Cl}=3.56 \quad \AA \quad$ [39] $)$ and $\mathrm{FcCH}_{2} \mathrm{NMe}_{3}^{+} \mathrm{I}^{-}$or $\mathrm{Fc}\left(\mathrm{CH}_{2} \mathrm{NMe}_{3}^{+}\right)_{2} 2 \mathrm{I}^{-}(\mathrm{CH} \cdots \mathrm{I}=3.73$ to $4.27 \AA$ [42]). The relatively longer $\mathrm{C} \cdots \mathrm{Cl}$ contacts in $1 d$ may be due to the additional hydrogen bonding to the cocrystallized water molecules.

\subsection{Electrochemistry}

The anodic electrochemistry of $\mathrm{FcCH}_{2} \mathrm{NMe}_{2} \mathrm{H}^{+}$has already been explored $[23,45]$ and our data are in complete agreement with previous findings. The ferrocene/ferrocenium couple exhibits Nernstian behavior and, upon protonation, is shifted anodically by $0.185 \mathrm{~V}$ with respect to the parent amine. Full reversibility also prevails on the somewhat extended timescale of chronoamperometric or chronocoulometric experiments. We also observed a totally (chemically and electrochemically) irreversible one electron reduction wave. The peak potential depends on the electrode material and changes from $-1.44 \mathrm{~V}$ at platinum and $-1.58 \mathrm{~V}$ at gold to $-1.84 \mathrm{~V}$ at glassy carbon. The chemical irreversibility does not allow for the observation of an associated anodic return wave. The electrochemical irreversibility leads to a broadening of the wave and a significantly 
Selected structural parameters for $\mathbf{2} \mathbf{d}, \mathbf{1 b}$ and the three independent cations of $\mathbf{1 d} \cdot 4 / 3 \mathrm{H}_{2} \mathrm{O}$

\begin{tabular}{|c|c|c|c|c|c|}
\hline & $2 d$ & lb & 1d (cation 1) & 1d (cation 2) & 1d (cation 3) \\
\hline $\mathrm{Fe}-\mathrm{C}\left(\mathrm{Cp}^{\mathrm{R}}\right)(\mathrm{av} .)^{\mathrm{a}}$ & 2.042 & 2.041 & 2.035 & 2.035 & 2.037 \\
\hline $\mathrm{Fe}-\mathrm{C}(\mathrm{Cp})(\mathrm{av} .)^{a}$ & 2.044 & 2.038 & 2.037 & 2.036 & 2.036 \\
\hline $\mathrm{C}\left(\mathrm{Cp}^{\mathrm{R}}\right)-\mathrm{C}\left(\mathrm{C} \mathrm{p}^{\mathrm{R}}\right)(\mathrm{av})$. & 1.428 & 1.422 & 1.427 & 1.422 & 1.420 \\
\hline $\mathrm{C}(\mathrm{Cp})-\mathrm{C}(\mathrm{Cp})$ (av.) & 1.414 & 1.389 & 1.406 & 1.410 & 1.408 \\
\hline $\mathrm{Fe}-\mathrm{Cp}^{\mathrm{R}}$ (centroid) ${ }^{\mathrm{b}}$ & 1.643 & $1.641 ; 1.646$ & $1.637 ; 1.633$ & $1.637 ; 1.637$ & $1.644 ; 1.634$ \\
\hline $\mathrm{Fe}-\mathrm{Cp}$ (centroid) ${ }^{\mathrm{b}}$ & 1.650 & $1.656 ; 1.660$ & $1.647 ; 1.649$ & $1.641 ; 1.647$ & $1.649 ; 1.648$ \\
\hline Dihedral angle ${ }^{c}$ & - & 10.9 & 16.4 & 5.8 & 7.4 \\
\hline Interplanar angle ${ }^{\mathrm{d}}$ & 2.1 & $0.9 ; 1.1$ & $1.5 ; 0.8$ & $1.8 ; 3.4$ & $0.8 ; 2.4$ \\
\hline Interplanar angle $\mathrm{e}^{\mathrm{e}}$ & - & 55.4 & 51.8 & 52.8 & 61.4 \\
\hline Rot. Angle ${ }^{f}$ & 3.8 & $3.6 ; 34.6$ & $1.4 ; 5.7$ & $14.2 ; 18.6$ & $16.0 ; 8.9$ \\
\hline
\end{tabular}

${ }^{a} \mathrm{Cp}^{\mathrm{R}}$ denotes the monosubstituted and $\mathrm{Cp}$ the unsubstituted carbocyclic ligands.

${ }^{\mathrm{b}}$ Defined by the distance of the Fe atom to the mean plane of the ring.

${ }^{c}$ Defined as the angle between the axes $\mathrm{Fe}-\mathrm{Cp}^{\mathrm{R}}$-centroid and a line connecting the two centroids.

${ }^{\mathrm{d}}$ Interplanar angle between the $\mathrm{Cp}$ and the $\mathrm{Cp}^{\mathrm{R}}$ ligands coordinated to the same $\mathrm{Fe}$ atom.

${ }^{\mathrm{e}}$ Interplanar angle between $\mathrm{Cp}^{\mathrm{R}}$ ligands coordinated to adjacent $\mathrm{Fe}$-atoms.

${ }^{f}$ Taken as the average of all angles $C\left(\mathrm{Cp}^{\mathrm{R}}\right)-\mathrm{Cp}^{\mathrm{R}}$ (centroid) $\mathrm{Cp}$ (centroid)-C (Cp) for the ring $\mathrm{C}$-atoms.

larger cathodic shift of the peak potential with increasing sweep rate as is accounted for by chemical irreversibility alone. From these data the electron transfer coefficient $\alpha$, a dimensionless parameter that describes the symmetry of the transition state of the electron transfer reaction, was determined as $0.43(0.02)$ [46]. If, after reduction, the sweep is continued to anodic potentials a new chemically reversible wave at ca. $-0.19 \mathrm{~V}$ with respect to the $\mathrm{FcCH}_{2} \mathrm{NMe}_{2} \mathrm{H}^{+/ 2+}$ couple appears. Since this feature is absent if the anodic sweep is performed first, the electrochemical reduction must be followed by a fast chemical reaction which in turn generates the new electroactive product detected on the reverse scan (ECE process, where $\mathrm{E}$ and $\mathrm{C}$ denote elctrochemical and chemical steps, respectively). The electrogenerated reduction product was readily identified as the parent amine $\mathrm{FCCH}_{2} \mathrm{NMe}_{2}$. When increasing amounts of the amine were added to the analyte solution, this new feature gained in height as conveniently shown by square wave voltammetry (Fig. 5). The one electron reduction of $\mathrm{FcCH}_{2} \mathrm{NMe}_{2} \mathrm{H}^{+}$is thus accompanied by the loss of hydrogen. This reaction is well known for tertiary ammonium salts [47] and explains the electrode material dependent reduction potentials and the sluggishness of the electron transfer.

The $\left(\mathrm{FcCH}_{2}\right)_{2} \mathrm{NMe}_{2}^{+}$cations present in $\mathbf{1 a}-\mathbf{d}$ comprise two electrochemically well behaved ferrocene subunits that are connected via a saturated CNC spacer. Related dinuclear systems have been extensively studied in view of the electronic communication between the identical redox centers. The degree of such interactions is a function of mainly two parameters: the electron delocalizing abilities of the bridging unit and the spatial separation and relative orientation of the two redox centers imposed by the bridge [48-50]. The differences in half wave potentials of the individual one electron events as determined by voltammetry constitutes one, however only qualitative, indicator for electronic interactions between the two identical redox sites [48,51]. The saturated $\mathrm{CNC}$ bridge is only a very poor delocalizer and so we expected to see only small differences in the $E_{1 / 2}$ values. In fact, both one electron steps occur in a single, slightly broadened wave of almost identical peak height as was observed for an equimolar quantity of the ferrocene standard. The close resemblance of the peak heights is due to a broadening of the wave caused by slight differences of the individual $E_{1 / 2}$ values and the opposite effects of the number of the transferred electrons $n$ and the diffusion coefficient $D$. In cyclic voltammetry, the peak current is proportional to $n^{3 / 2} \cdot D^{1 / 2}$. Once $n$ is known, $D$ is easily accessible from chronoamperometry by determining the slope of $i(t)$ versus $t^{-1 / 2}$ plots. We obtained a value of $0.86 \times 10^{-5}(0.02) \mathrm{cm}^{2} \mathrm{~s}^{-1}$ which is about one third the value reported for ferrocene by Kochi et al. [52,53]. The two electron nature of this wave was independently confirmed by comparing the diffusion controlled currents in a large amplitude potential step experiment and the limitting currents from steady state voltammetry for $\left(\mathrm{FcCH}_{2}\right)_{2} \mathrm{NMe}_{2}^{+}$with those of the ferrocene standard as suggested by Baranski et al. [54] and finally by controlled potential electrolysis. Ferrocene was also employed as an internal redox standard to determine the exact degree of wave broadening in terms of the differences in peak potentials $\Delta E_{\mathrm{p}}$ and half widths $E_{\mathrm{p}}-E_{\mathrm{p} / 2}$. These parameters are diagnostic tools that give access to the individual $E_{1 / 2}$ values [55]. Our findings were additionally supported by digital simulation. Best fit parameters are listed in Table 5 and were obtained over a 10 -fold increase in $v$ for either $\mathrm{CH}_{3} \mathrm{CN}$, propylene carbonate or DMF solutions. We expect these data to be accurate within a $\pm 1 \mathrm{mV}$ range for $\mathrm{CH}_{3} \mathrm{CN}$ and propylene carbonate and $\pm 2 \mathrm{mV}$ for DMF since the experimental results and the best fit data differed by no more than that from each other. According to Eq. (5), $\Delta E_{1 / 2}$ values can be translated into equilibrium constants 

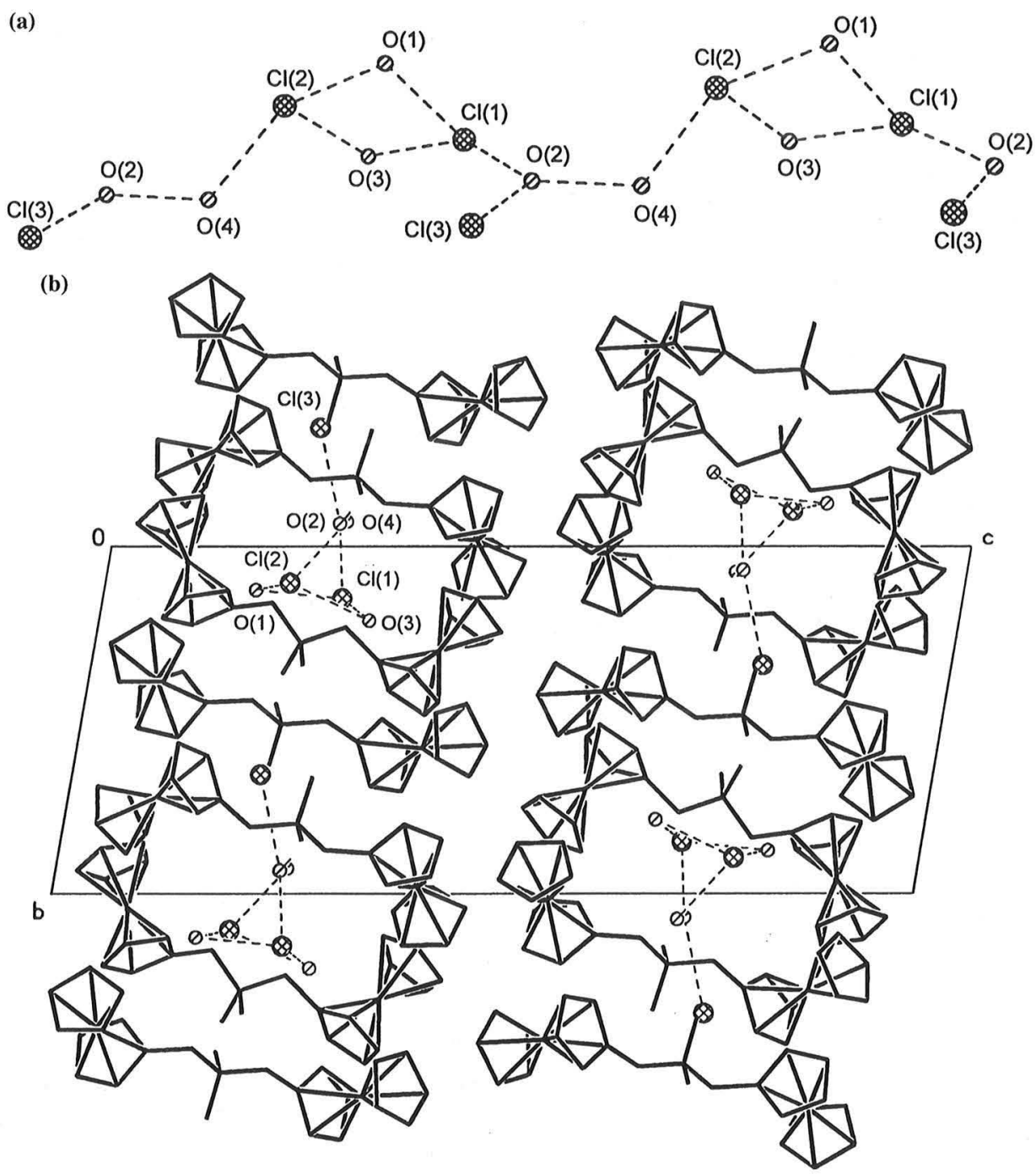

Fig. 4. (a) View of a one dimensional chain comprised of hydrogen bonded $\mathrm{Cl}^{-}$and $\mathrm{H}_{2} \mathrm{O}$ in the structure of $1 \mathrm{~d} \cdot 4 / 3 \mathrm{H}_{2} \mathrm{O}$. (b) $\mathrm{Packing}$ diagram of $\left(1 \mathrm{~d} \cdot 4 / 3 \mathrm{H}_{2} \mathrm{O}\right)$. One of the $\mathrm{Cl}^{-}$ions is statistically replaced by $\mathrm{CN}^{-}$(not shown).

$K_{\mathrm{c}}$ for the comproportionation reaction in Eq. (6). These values are also listed in Table 5. One should, however, note that the wave splitting may rather be due to coulombic interactions between the increasingly charged redox centers than to electronic interactions between the two sites. This thought is strongly supported by UV-vis/ NIR spectro-electrochemical experiments in an optical transparent thin layer electrolysis (OTTLE) cell. From simple statistics one may deduce that after passage of only one equivalent of charge the monooxidized, mixed valent form must be the predominant species. The presence and strength of the electronic coupling between the two different redox sites can be inferred from the appearance and shape of an intervalence charge transfer band in the near IR [56]. Even when concentrated solutions were electrolysed gradually and slowly we were never able to detect any absorption in the NIR region down to $2600 \mathrm{~cm}^{-1}$. This result argues against any significant electronic interactions between the two ferro- cenyl subunits in $\mathbf{1 a - d}$.

$K_{\mathrm{c}}=\exp \left(\Delta E_{1 / 2} n F / R T\right)$

$\left(\mathrm{FcCH}_{2}\right)_{2} \mathrm{NMe}_{2}^{+}+\left(\mathrm{FcCH}_{2}\right)_{2} \mathrm{NMe}_{2}^{3+}$

$\left.\rightleftharpoons 2 \mathrm{FcCH}_{2}\right)_{2} \mathrm{NMe}_{2}^{2+}$

The reduction of the $\left(\mathrm{FcCH}_{2}\right)_{2} \mathrm{NMe}_{2}^{+}$cation occurs outside the potential range accessible in $\mathrm{CH}_{3} \mathrm{CN}$ but may well be studied in propylene carbonate or DMF (see Fig. 6). Again, the reduction is a chemically irreversible process. Unlike for the protonated $\mathrm{FcCH}_{2} \mathrm{NMe}_{2} \mathrm{H}^{+}$, however, the peak potential does not depend on the electrode material and the electron transfer rate is much higher with $K_{\mathrm{s}}$ in the range of ca. $0.1 \mathrm{~cm}^{\cdot} \mathrm{s}^{-1}$. An even more striking difference is its two electron nature. This is evident from the only slightly decreased peak heights and the identical slopes of $i(t)$ versus $t^{-1 / 2}$ plots in chronoamperometry for the oxidation and the reduction waves. According to digital simulations the individual 


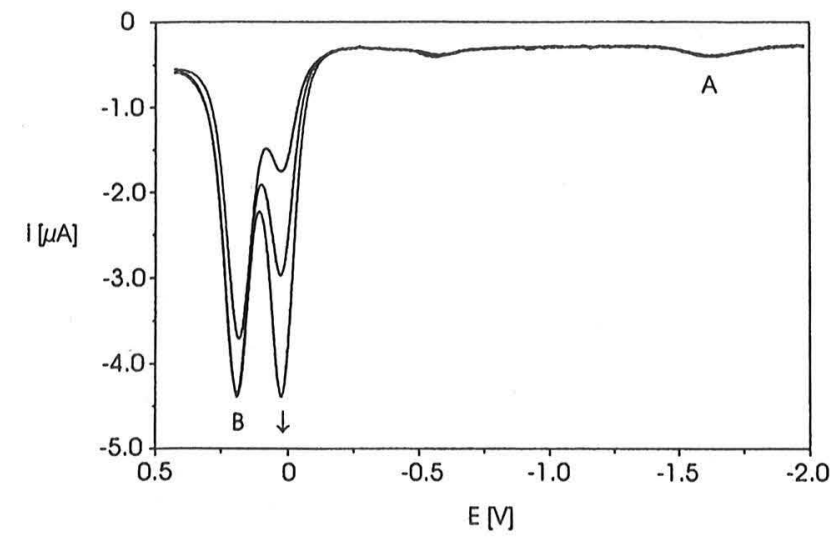

Fig. 5. Square wave voltammograms of $\mathrm{FCCH}_{2} \mathrm{NMe}_{2} \mathrm{H}^{+}$. The sweep is initiated negative of the irreversible reduction peak A. Peak B is due to the reversible oxidation. The lower trace represents the voltammogram obtained from the pure compound while the two upper traces were recorded after addition of increasing amounts of $N, N$-(dimethylaminomethyl)ferrocene.

$E^{\mathrm{o}}$ values for the two one electron uptake events can not be separated by more than $20 \mathrm{mV}$. This is rather surprising since quaternary ammonium salts usually undergo a one electron reduction followed by the cleavage of one of the $\mathrm{C}-\mathrm{N}$ bonds according to Eq. (7) [47]. In the $\left(\mathrm{FcCH}_{2}\right)_{2} \mathrm{NMe}_{2}^{+}$cation the bond rupture can occur in two different ways with either the loss of a methyl or a ferrocenyl substituent. Since earlier work points to the preferential formation of the more stable fragments [48] one may expect to see $\mathrm{FcCH}_{2} \mathrm{NMe}_{2}$ resulting from the reduction of $\left(\mathrm{FCCH}_{2}\right)_{2} \mathrm{NMe}_{2}^{+}$. If after sweeping past the peak of the cathodic wave the scan is reversed a new reversible feature does indeed appear at $0.185-0.245 \mathrm{~V}$ negative of the oxidation wave, depending on the solvent. The peak potentials agree well with those of the $\mathrm{FcCH}_{2} \mathrm{NMe}_{2}^{0 /+}$ couple in the respective solvents. Addition of this amine to the analyte solution causes the new feature to gain in peak height but also induces a slight anodic displacement of the wave. At the present stage we can therefore not exclude that the $\mathrm{C}-\mathrm{N}$ bond cleavage, in part or even completely, occurs in the opposite sense nor can we explain the two electron nature of the reduction wave. In view of the electrochemical behavior of $\left(\mathrm{FcCH}_{2}\right)_{2} \mathrm{NMe}_{2}^{+}$one may reasonably expect the two ferrocenyl subunits of a neutral biferrocenyl-

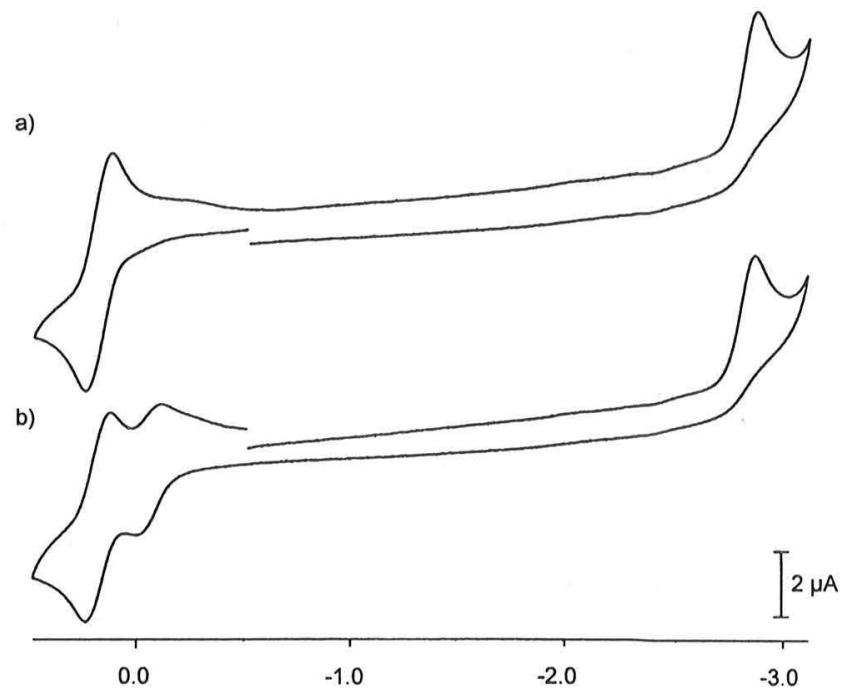

Fig. 6. Cyclic voltammograms of the $\left(\mathrm{FcCH}_{2}\right)_{2} \mathrm{NMe}_{2}^{+}$ion; (a) initial sweep in the anodic direction, (b) initial sweep in the cathodic direction. The new reversible feature in curve (b) is due to an electrogenerated product following reduction.

amine $\left(\mathrm{FcCH}_{2}\right)_{2} \mathrm{NMe}$ that would result from the latter cleavage reaction to be oxidized in a single wave at potentials not much different from those of $\mathrm{FcCH}_{2} \mathrm{NMe}_{2}$.

$\mathrm{R}^{\prime} \mathrm{NR}_{3}^{+}+\mathrm{e}^{-} \rightarrow \mathrm{R}^{\prime \bullet}+\mathrm{NR}_{3}$

\subsection{Preparation and spectroscopic characterization of the corresponding ferrocenium salts}

The oxidized monoferrocenium ion $\mathrm{FcCH}_{2} \mathrm{NMe}_{2} \mathrm{H}^{2+}$ and the dioxidized bisferrocenium ion $\left(\mathrm{FcCH}_{2}\right)_{2} \mathrm{NMe}_{2}^{3+}$ are accessible by a variety of methods, including electrochemical oxidation in a preparative three compartment cell or a thin layer cell and chemical oxidation. As oxidizing agents $\mathrm{Ag}^{+}$or $\mathrm{NO}^{+}$in $\mathrm{CH}_{2} \mathrm{Cl}_{2}$ or $\mathrm{CH}_{3} \mathrm{NO}_{2}$ or $\mathrm{H}_{2} \mathrm{SO}_{4}$ or triflic acid in the presence of $\mathrm{H}_{2} \mathrm{O}_{2}$ and oxygen in water were successfully employed ([10]b). For the ease of preparation and purification, the oxidation of $\mathrm{FcCH}_{2} \mathrm{NMe}_{2} \mathrm{H}^{+}$with $\mathrm{NO}^{+}$in $\mathrm{CH}_{3} \mathrm{CN}$ and of $\left(\mathrm{FcCH}_{2}\right)_{2} \mathrm{NMe}_{2}^{+}$with $\mathrm{Ag}^{+}$in $\mathrm{CH}_{3} \mathrm{NO}_{2}$ is recommended. The oxidized species are only sparingly soluble or insoluble in $\mathrm{CH}_{2} \mathrm{Cl}_{2}$, but dissolve very well in $\mathrm{CH}_{3} \mathrm{NO}_{2}$,

Table 5

Redox potentials for $\left(\mathrm{FcCH}_{2}\right)_{2} \mathrm{NMe}_{2}^{+\mathrm{a}, \mathrm{b}}$

\begin{tabular}{lllllll}
\hline Solvent & $E_{1 / 2}^{+2+}(\mathrm{V})$ & $E_{1 / 2}^{2+3+}(\mathrm{V})$ & $\Delta E(\mathrm{~V})$ & $K_{\mathrm{c}}$ & $E_{\mathrm{p}}^{\mathrm{red}}(\mathrm{V})$ & $E_{1 / 2}^{\mathrm{ECE}}(\mathrm{V})^{\mathrm{c}}$ \\
\hline $\mathrm{CH}_{3} \mathrm{CN}$ & $0.180(1)$ & $0.243(1)$ & $0.063(2)$ & $12(1)$ & - & - \\
$\mathrm{PC}$ & $0.164(1)$ & $0.234(1)$ & $0.070(2)$ & $16(1)$ & -2.89 & -0.04 \\
$\mathrm{DMF}$ & $0.150(2)$ & $0.224(2)$ & $0.074(4)$ & $19(3)$ & -2.94 & -0.06 \\
\hline
\end{tabular}

${ }^{a}$ Values in brackets are standard deviations.

${ }^{b}$ All potentials referenced to the $\mathrm{Fc}^{0 /+}$ couple as internal redox standard.

${ }^{\mathrm{c}} E_{1 / 2}$ of the new species generated by the ECE reduction process. 
$\mathrm{CH}_{3} \mathrm{CN}$ or $\mathrm{CH}_{3} \mathrm{OH}$, forming quite air stable, intense blue to blue-green solutions with red to purple dichroism. Solutions of $\mathrm{FcCH}_{2} \mathrm{NMe}_{2} \mathrm{H}^{2+}$ in $\mathrm{CH}_{3} \mathrm{NO}_{2}$ or $\mathrm{CH}_{3} \mathrm{CN}$ slowly decompose even under an argon atmosphere. Solid $\left(\mathrm{FcCH}_{2}\right)_{2} \mathrm{NMe}_{2}^{3+}$ salts of weakly coordinating cations may be stored for weeks under ambient conditions without any detectable degradation. The ferrocenium salts were characterized by UV-vis, IR and ESR spectroscopy. ESR spectra were recorded at $4 \mathrm{~K}$ and closely resemble those of other substituted ferrocenium salts ([10]a). They exhibit axial patterns with $g_{\mathrm{II}}=4.35$ $\left(\Delta H_{\mathrm{II}}=120 \mathrm{G}\right), \quad g_{\perp}=1.42 \quad\left(\Delta H_{\perp}=1200 \mathrm{G}\right)$ for $\mathrm{FcCH}_{2} \mathrm{NMe}_{2} \mathrm{H}^{2+}$ and $g_{\mathrm{II}}=4.15\left(\Delta H_{\mathrm{II}}=250 \mathrm{G}\right), g_{\perp}=$ $1.48\left(\Delta H_{\perp}=1200 \mathrm{G}\right)$ for the fully oxidized $\left(\mathrm{FcCH}_{2}\right)_{2} \mathrm{NMe}_{2}^{3+}$. UV-vis spectra were obtained from either electrochemical oxidation in an OTTLE cell or from the isolated oxidation products themselves (Fig. 7). Upon gradual oxidation of $\mathbf{2} \mathbf{b}$ and $\mathbf{1 b}$ the characteristic ${ }^{1} \mathrm{~A}_{1 \mathrm{~g}} \rightarrow{ }^{1} \mathrm{E}_{1 \mathrm{~g}}$ and ${ }^{1} \mathrm{~A}_{\mathrm{lg}} \rightarrow{ }^{1} \mathrm{E}_{1 \mathrm{~g}},{ }^{1} \mathrm{E}_{2 \mathrm{~g}}$ bands centered at ca. 325 and $435 \mathrm{~nm}$ (Table 1) are displaced by much more
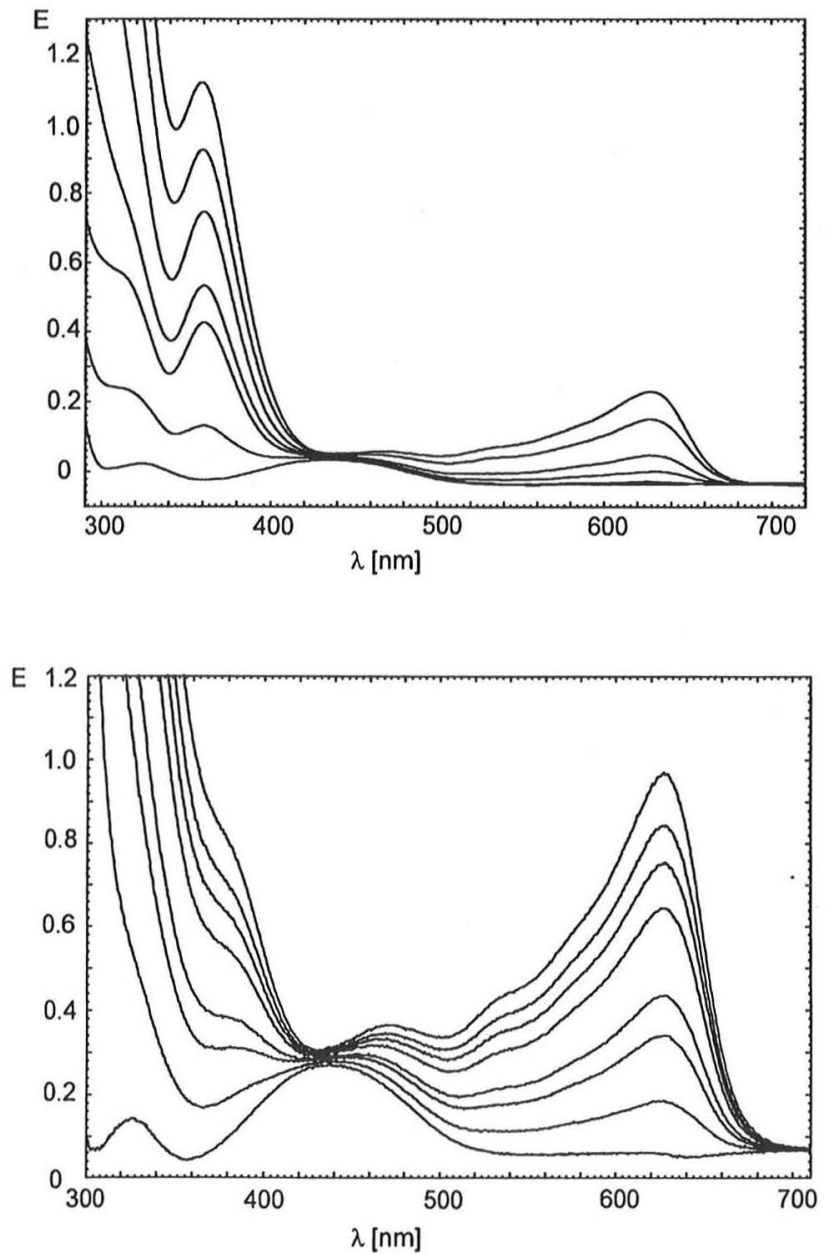

Fig. 7. UV-vis traces during the oxidation of the $\mathrm{FcCH}_{2} \mathrm{NMe}_{2} \mathrm{H}^{+}$ ion (top) and the $(\mathrm{FcCH})_{2} \mathrm{NMe}_{2}^{+}$ion (bottom) in an OTTLE cell. In both cases the lowest curve represents the spectra before oxidation and the uppermost trace the spectra after complete oxidation to the ferrocenium ions. intense absorptions of the ferrocenium chromophore [57]. In the visible region the spectra are dominated by a fairly intense charge transfer band at $\lambda_{\max }=627 \mathrm{~nm}$ with several ligand field transitions based on the ${ }^{2} E_{2 g}$ ground state superimposed as shoulders on the high energy part of this band or discernable as discrete peaks (see Section 3). As in other ferrocenium systems, the IR spectra are less well resolved than those of the reduced counterparts and exhibit considerably fewer peaks. We note that air stable $\left(\mathrm{FcCH}_{2}\right)_{2} \mathrm{NMe}_{2}^{3+}$ salts are available from commercial products in an easy, high-yield, twostep synthesis. They are capable of transferring two electrons at virtually the same potential and may be useful as a convenient oxidizing agent with an oxidizing power comparable to that of the acetylferrocenium ion.

\section{Experimental}

All manipulations apart from those involving $\mathrm{Me}_{2} \mathrm{~N}=\mathrm{CH}_{2}^{+} \mathrm{Cl}^{-}$and oxidation reactions with $\mathrm{NO}^{+}$ were performed in undried solvents without any precautions to exclude moisture or air. Ferrocenylmethyldimethylamine was purchased from Lancaster and used as received. The deuterated solvents were supplied by Aldrich. Infrared spectra were obtained on a Perkin Elmer Paragon 1000 PC FT-IR instrument. ' $\mathrm{H}$ $(250.13 \mathrm{MHz})$ and ${ }^{13} \mathrm{C}(62.90 \mathrm{MHz}) \mathrm{NMR}$ spectra were recorded on a Bruker AC 250 spectrometer at $303 \mathrm{~K}$ in $\mathrm{CD}_{3} \mathrm{CN}$ unless stated otherwise. For the in situ reactions of $\mathrm{FcCH}_{2} \mathrm{NMe}_{2}$ in $\mathrm{CD}_{2} \mathrm{Cl}_{2}$ the $\mathrm{NMR}$ tubes were sealed to maintain a constant solvent volume. The spectra were referenced to the residual protonated solvent $\left({ }^{1} \mathrm{H}\right)$ or the solvent signal itself $\left({ }^{13} \mathrm{C}\right)$. If necessary, the assignment of ${ }^{13} \mathrm{C}-\mathrm{NMR}$ spectra was aided by appropriate DEPT measurements [58]. UV-vis experiments were performed with a Shimadzu UV-160 spectrometer in HELMA quartz cuvettes with $1 \mathrm{~cm}$ optical path lengths. The ESR equipment consists of a Bruker ESP 3000 spectrometer equipped with a HP frequency counter $5350 \mathrm{~B}$, a Bruker NMR gaussmeter ER $035 \mathrm{M}$ and a continuous flow cryostat ESR 900 from Oxford Instruments for low temperature work. Elemental analyses $(\mathrm{C}, \mathrm{H}, \mathrm{N})$ were performed at inhouse facilities. Theoretical yields are calculated based on the overall reaction stoichiometry in Scheme 1.

All electrochemical experiments were performed in a home-built cylindrical vacuum tight one compartment cell. A spiral shaped $\mathrm{Pt}$ wire and a $\mathrm{Ag}$ wire as the counter and reference electrodes were sealed directly into opposite sides of the glass wall while the respective working electrodes (Pt $350 \mu \mathrm{m}$, glassy carbon $1.1 \mathrm{~mm}$, Au $60 \mu \mathrm{m}$ diameter, polished with $0.25 \mu \mathrm{m}$ diamond paste (Buehler-Wirtz) before each experiment) were introduced via a teflon screw cap with a suitable fitting. The cell may be attached to a conventional Schlenk line 
via two sidearms equipped with teflon screw valves and allows experiments to be performed under an atmosphere of argon with approximately $2.5 \mathrm{ml}$ of analyte solution. The solvents were obtained in the highest available purity from commercial sources $\left(\mathrm{CH}_{2} \mathrm{Cl}_{2}\right.$ and propylene carbonate from Fluka (Burdick and Jackson), $\mathrm{CH}_{3} \mathrm{CN}$ (HPLC Gradient Grade) from Roth) and treated with alumina (2-5 mm particles for drying purposes from Fluka) while being freeze-pump-thaw degassed (three times) or purged with argon (at least $20 \mathrm{~min}$ ). $\mathrm{NBu}_{4} \mathrm{PF}_{6}$ $\left(\mathrm{CH}_{2} \mathrm{Cl}_{2}, \mathrm{CH}_{3} \mathrm{CN}\right)$ or $\mathrm{NBu}_{4} \mathrm{ClO}_{4}$ (propylene carbonate, $0.25 \mathrm{mM}$ each) were used as the supporting electrolytes. All potentials are referenced versus ferrocene. All electrochemical data were acquired with a computer controlled EG\&G model 273 potentiostat utilizing the EG\&G 250 software package. Controlled potential electrolyses were performed in a home built, air-tight three compartment cell with electrodes (working electrode: Pt-basket, $3 \mathrm{~cm}$ diameter, auxiliary electrode: Pt-basket $1 \mathrm{~cm}$ diameter, reference electrode: Ag-rod, $3 \mathrm{~mm}$ diameter) sealed directly into the glass. The OTTLE cell was also home built and comprised a Pt-mesh working and counter electrode and a thin silver wire as a pseudo-reference electrode sandwiched between the $\mathrm{CaF}_{2}$ windows of a conventional liquid IR cell. The working electrode was positioned in the center of the spectrometer beam. Digital simulations of experimental CVs were performed with DigiSim $^{\circledR}$ (version 2.1) available from BAS.

\subsection{Syntheses of $\left(\mathrm{FCCH}_{2}\right)_{2} \mathrm{NMe}_{2}^{+} \mathrm{X}^{-}\left(\mathrm{X}^{-}=\mathrm{PF}_{6}^{-}\right.$ (1a), $\left.S b F_{6}^{-}(1 b)\right)$}

$\mathrm{FcCH}_{2} \mathrm{NMe}_{2}(0.245 \mathrm{~g}, 1.01 \mathrm{mmol})$ was dissolved in $\mathrm{CH}_{2} \mathrm{Cl}_{2}(25 \mathrm{ml})$ and an equimolar amount of $\mathrm{NaEF}_{6}$ $(\mathrm{E}=\mathrm{P}, 0.171 \mathrm{~g} ; \mathrm{E}=\mathrm{Sb}, 0.265 \mathrm{~g})$ added as a solid. The suspension was stirred for 3 days under ambient conditions. The solution was then transferred to a flask by filter cannula and the solvent removed in vacuo. The resultant tarry residue was extracted into a warm $2: 1$ chlorobenzene $/ \mathrm{CH}_{3} \mathrm{CN}$ mixture $(10 \mathrm{ml}$; caution: extensive warming will result in decomposition as indicated by the formation of a dark brown insoluble material). The solution was filtered, slowly cooled and concentrated. After 2-3 days $\left(\mathrm{FcCH}_{2}\right)_{2} \mathrm{NMe}_{2}^{+} \mathrm{EF}_{6}^{-}$crystallized as orange-yellow needles $\left(\mathrm{PF}_{6}^{-}\right)$or large hexagonal plates $\left(\mathrm{SbF}_{6}^{-}\right)$. Yields: 1a: $0.116 \mathrm{~g}, 0.24 \mathrm{mmol}, 59 \%$. Anal. found: $\mathrm{C}, 48.56$; $\mathrm{H}$, 4.88; N, 2.34. $\mathrm{C}_{24} \mathrm{H}_{28} \mathrm{~F}_{6} \mathrm{Fe}_{2} \mathrm{P}$ requires $\mathrm{C}, 49.09, \mathrm{H}, 4.81$; $\mathrm{N}, 2.40$. NMR and IR spectra display besides the signals of the cation (for NMR data see Table 1) those of the $\mathrm{PF}_{6}^{-}$anion: ${ }^{31} \mathrm{P} \delta-143.9$ (hept, $J_{\mathrm{PF}}=706.6 \mathrm{~Hz}$ ). ${ }^{19} \mathrm{~F} \delta$ $-67.6\left(\mathrm{~d}, J_{\mathrm{PF}}=706.6 \mathrm{~Hz}\right)$. IR $v$ 838(vs), 557(m). Bands of the cation: $v$ 3096(m), 3086(m), 3046(w), 3038(w), 2964(m), 1580(w), 1478(s), 1450(m), 1444(m), 1430(m), 1406(m), $1375(\mathrm{w}), 1331(\mathrm{~m}), 1261(\mathrm{w}), 1238(\mathrm{~m}), 1105(\mathrm{~s})$, 1043(m), 1032(m), 1012(m), 1000(m), 980(w), 920(w), 845(sh), 825(vs), 547(m), 485(s, br), 451(w), 420(w). 1b: $0.154 \mathrm{~g}, 67 \%$. Anal. found: C, 42.39; H, 3.84; N, 2.11. $\mathrm{C}_{24} \mathrm{H}_{28} \mathrm{~F}_{6} \mathrm{Fe}_{2} \mathrm{Sb}$ requires $\mathrm{C}, 42.27, \mathrm{H}, 4.13 ; \mathrm{N}, 2.05$. IR spectra display besides the signals of the cation those of the $\mathrm{SbF}_{6}^{-}$anion: IR $v$ 657(vs), 291(s).

\subsection{Synthesis of $\left(\mathrm{FcCH}_{2}\right)_{2} \mathrm{NMe}_{2}^{+} \mathrm{BPh}_{4}^{-}(\mathbf{I c})$}

$\mathrm{FcCH}_{2} \mathrm{NMe}_{2}(0.243 \mathrm{~g}, 1.0 \mathrm{mmol})$ was dissolved in $\mathrm{CH}_{2} \mathrm{Cl}_{2}(20 \mathrm{ml})$ and solid $\mathrm{NaBPh}_{4}(0.358 \mathrm{~g}, 1.05 \mathrm{mmol})$ added. The yellow-orange suspension was stirred for 3 days under ambient conditions. The resulting orange solid was allowed to settle and isolated by removing the mother liquor via filter cannula. It was washed with two additional $3 \mathrm{ml}$ portions of cold $\mathrm{CH}_{2} \mathrm{Cl}_{2}$ and dried in vacuo. Yield: $0.185 \mathrm{~g}, 0.24 \mathrm{mmol}, 72 \%$. The mother liquor still contains appreciable amounts of the product and $\mathrm{FcCH}_{2} \mathrm{NMe}_{2} \mathrm{H}^{+} \mathrm{BPh}_{4}^{-}$. Attempts to separate the two components by fractional crystallization were unsuccessful. Anal. found: C, 75.56; H, 6.28; N, 1.90 . $\mathrm{C}_{48} \mathrm{H}_{48} \mathrm{BFe}_{2} \mathrm{~N}$ requires $\mathrm{C}, 75.71$. $\mathrm{H}, 6.35 ; \mathrm{N}, 1.84$. NMR and IR spectra show in addition to the cation signals those characteristic of the $\mathrm{BPh}_{4}^{-}$anion $\left({ }^{1} \mathrm{H} \delta 7.27\right.$ (br, $8 \mathrm{H}) ; 7.00\left(\mathrm{t},{ }^{3} J_{\mathrm{HH}}=7.40 \mathrm{~Hz}, 8 \mathrm{H}\right) ; 6.84\left(\mathrm{t},{ }^{3} J_{\mathrm{HH}}=7.40 \mathrm{~Hz}\right.$, $4 \mathrm{H}$ ). ${ }^{13} \mathrm{C} \delta 160.9$ (non-binomial q, $J_{\mathrm{BC}}=60 \mathrm{~Hz}$ ); 131.0, 129.4, 127.8(all s). IR $v 1580(\mathrm{~m}), 1428(\mathrm{~s}), 1261(\mathrm{~m}), 1183$ (m), 1152(m), 866(m), 850(s), 737(vs), 729(vs), 708(vs)) [59].

\subsection{Synthesis of $\left(\mathrm{FCCH}_{2}\right)_{2} \mathrm{NMe}^{2+} \mathrm{Cl}^{-}$(1d)}

A solution of $\mathrm{FcCH}_{2} \mathrm{NMe}_{2}(0.128 \mathrm{~g}, 0.53 \mathrm{mmol})$ in 10 $\mathrm{ml} \mathrm{CH}_{2} \mathrm{Cl}_{2}$ was stirred at room temperature for 3 days, the solvent evaporated and the tarry residue dissolved in a minimum amount of warm $\mathrm{CH}_{3} \mathrm{CN}$. After filtration, the solvent was allowed to slowly evaporate until small amber crystals had formed. One more crop was obtained upon further concentration of the mother liquor. Combined yield: $0.059 \mathrm{~g}(0.165 \mathrm{mmol}), 70 \%$. Anal. found: $\mathrm{C}$, 59.93; $\mathrm{H}, 6.00 ; \mathrm{N}, 2.91 . \mathrm{C}_{24} \mathrm{H}_{28} \mathrm{ClFe}_{2} \mathrm{~N}$ requires $\mathrm{C}, 60.34$, $\mathrm{H}, 5.91 ; \mathrm{N}, 2.95$

\subsection{Synthesis of $\mathrm{FcCH}_{2} \mathrm{NMe}_{2} \mathrm{H}^{+} \mathrm{SbF}_{\bar{\sigma}}^{-}$(2b)}

$\mathrm{FcCH}_{2} \mathrm{NMe}_{2}(0.577 \mathrm{~g}, 2.37 \mathrm{mmol})$ was dissolved in a suspension of $\mathrm{NaSbF}_{6}(1.24 \mathrm{~g}, 5.75 \mathrm{mmol})$ in $20 \mathrm{ml}$ $\mathrm{CHCl}_{3}$ and stirred for 2 days at room temperature. The resulting orange solid was filtered off, dried in vacuo and extracted into $15 \mathrm{ml}$ of $\mathrm{CH}_{2} \mathrm{Cl}_{2}$. The yellow-orange solution was put to dryness to leave an orange powder. The mother liquor was concentrated in vacuo and purified by column chromatography (neutral alumina, $15 \times 3 \mathrm{~cm}, 4 \% \mathrm{H}_{2} \mathrm{O}$ in $\mathrm{CH}_{3} \mathrm{CN}$ as eluant). The product was obtained as an orange fraction. Combined yields $0.657 \mathrm{~g}, 1.38 \mathrm{mmol}, 58 \%$. Anal. found: C, 32.65; H, 3.78; $\mathrm{N}, 2.88 . \mathrm{C}_{13} \mathrm{H}_{18} \mathrm{~F}_{6} \mathrm{FeNSb}$ requires $\mathrm{C}, 32.54, \mathrm{H}, 3.78 ; \mathrm{N}$, 2.92. IR: $v$ (cation) 3235(m), 3100(w), 2960(w), 2734(w), 
1475(vs), 1450(m), 1430(s), 1421(s), 1401(m), 1382 (m), 1332(w), 1292(w), 1261(vw), 1235(m), 1165(m), 1123(m), $1105(\mathrm{~s}), 1060(\mathrm{~m}), 1040(\mathrm{~m}), 1022(\mathrm{~m}), 1014(\mathrm{~m}), 1001(\mathrm{~m})$, 947(m), 920(s), 845(m), 820(vs), 516(m), 500(m), 485(s), 446(m), 313(m).

\subsection{NMR spectroscopic investigation of the reaction of} $\mathrm{FCCH}_{2} \mathrm{NMe}_{2}$ in $\mathrm{CD}_{2} \mathrm{Cl}_{2}$

$\mathrm{FcCH}_{2} \mathrm{NMe}_{2}$ (54 mg, $0.22 \mathrm{mmol}$ ) was balanced into a screw cap NMR tube and $\mathrm{CD}_{2} \mathrm{Cl}_{2}(1.21 \mathrm{~g}, 0.9 \mathrm{ml})$ added. The NMR tube was tightly closed and NMR spectra recorded continuously over a $28 \mathrm{~h}$ period after mixing $\left({ }^{1} \mathrm{H}\right.$ initially every 30 , then every $90 \mathrm{~min}$ with intermediate recording of ${ }^{13} \mathrm{C}$-NMR spectra; additional spectra were acquired after 2 and 3 days, respectively). The reaction was accompanied by the growth of the signals of $\left(\mathrm{FcCH}_{2}\right)_{2} \mathrm{NMe}_{2}^{+}$and a continuous downfield shift of the signals due to the starting material. At the end of the reaction the shift data for this second set of signals almost match those of pure $2 \mathbf{d}$. In the course of the reaction new NMR signals appeared: ${ }^{1} \mathrm{H} \delta 4.77\left(\mathrm{t},{ }^{3} J_{\mathrm{HH}}=1.96 \mathrm{~Hz}\right)$, $4.60\left(\mathrm{t},{ }^{3} J_{\mathrm{HH}}=1.96 \mathrm{~Hz}\right), 4.27(\mathrm{~s}), 2.57(\mathrm{~s}), 2.36(\mathrm{~s}), 2.32(\mathrm{~s})$; ${ }^{13} \mathrm{C} \delta 78.0(\mathrm{br}), 73.5,70.2,45.0,41.5$.

\subsection{Reaction of $\mathrm{FcCH}_{2} \mathrm{NMe}_{2}$ with $\mathrm{Me}_{2} \mathrm{~N}=\mathrm{CH}_{2}^{+} \mathrm{Cl}^{-}$}

Under $\mathrm{Ar}, \mathrm{Me}_{2} \mathrm{~N}=\mathrm{CH}_{2}^{+} \mathrm{Cl}^{-}(27 \mathrm{mg}, 0.288 \mathrm{mmol})$ were balanced into an NMR tube and a solution of $72 \mathrm{mg}(0.29$ mmol) $\mathrm{FcCH}_{2} \mathrm{NMe}_{2}$ in $\mathrm{CD}_{2} \mathrm{Cl}_{2}$ added. The NMR tube was closed with an air tight screw cap and NMR spectra acquired over the course of $4 \mathrm{~h}$. An additional experiment was performed in $\mathrm{CD}_{3} \mathrm{CN}$ on a $0.225 \mathrm{mmol}$ scale. After full equilibration was obtained, the samples were removed from the NMR tubes and slowly added to rapidly stirred $\mathrm{Et}_{2} \mathrm{O}(15 \mathrm{ml})$ which caused the precipitation of an orange solid. The solvent was removed by filter cannula and the solid dried in vacuo. Yield: $0.11 \mathrm{~g}$. NMR spectroscopic investigation of the orange powder revealed the presence of $\mathrm{FcCH}_{2} \mathrm{NMe}_{2} \mathrm{H}^{+}$and $\left(\mathrm{FcCH}_{2}\right)_{2} \mathrm{NMe}_{2}^{+}$in an approximate ratio of 20:1.

\subsection{The reaction of $\mathrm{FcCH}_{2} \mathrm{NMe}_{2} \mathrm{H}^{+}$with $\mathrm{Me}_{2} \mathrm{NCH}_{2} \mathrm{NMe}_{2}$}

$N, N$-(Dimethylaminomethyl)ferrocene hydrochloride $48 \mathrm{mg}(0.17 \mathrm{mmol})$ was dissolved in $\mathrm{CD}_{2} \mathrm{Cl}_{2}$ and added to a NMR tube which was closed with a septum screw cap. A total of eight 0.25 equivalent aliquots of the aminal were added in portions via microliter syringe. The sample was allowed to equilibrate for $20 \mathrm{~min}$ after each consecutive addition and then NMR spectra were acquired. They showed a continuous upfield shift for the signals associated with the substituted ferrocene as well as a low field shift for those of the aminal.

\subsection{Trapping experiments with $\mathrm{LiH}, \mathrm{NaBH}_{4}$ and $\mathrm{KCN}$}

These reactions were performed on a $1 \mathrm{mmol}$ scale in $25 \mathrm{ml}$ of $\mathrm{CH}_{2} \mathrm{Cl}_{2}$ with a 4- to 5-fold excess of the trapping reagent. After 3 days of stirring under ambient conditions, the orange suspensions were filtered with a paper tipped cannula and the solvent stripped off in vacuo. The oily or tarry residues were purified by column chromatography on neutral alumina with a $5 \% \mathrm{H}_{2} \mathrm{O} / \mathrm{CH}_{3} \mathrm{CN}$ mixture as the eluant. A dark orange zone was rapidly eluted followed by two well separated yellow-orange fractions. The fractions were collected, stirred over anhydrous $\mathrm{MgSO}_{4}$ for $1 \mathrm{~h}$, filtered and the solvents removed on a rotary evaporator. The first fraction yielded a small amount of a dark orange oil, whereas the second and third fractions were obtained as orange microcrystals. Yields: Fraction 1: $6-10 \mathrm{mg}$. Fraction 2: $\left(\mathrm{FcCH}_{2}\right)_{2} \mathrm{NMe}_{2}^{+} \mathrm{Cl}^{-}\left(\mathbf{1 d} \cdot 4 / 3 \mathrm{H}_{2} \mathrm{O}\right)$ 0.094-0.113 g, 0.19$0.22 \mathrm{mmol}, 56-67 \%$. Anal. found: C, 57.47; H, 6.27; N, 2.83. $\mathrm{C}_{24} \mathrm{H}_{28} \mathrm{ClFe}_{2} \mathrm{~N} \cdot 4 / 3 \mathrm{H}_{2} \mathrm{O}$ requires $\mathrm{C}, 57.46, \mathrm{H}, 6.16$; $\mathrm{N}, 2.79$. NMR spectra of the hydrated samples are given in Table 1. Fraction 3: $\mathrm{FcCH}_{2} \mathrm{NMe}_{2} \mathrm{H}^{+} \mathrm{Cl}-$ (2d) $0.087-$ 0.091 g, 94-98\%. Anal. found: C, 55.79; H, 6.49; N, 5.00. $\mathrm{C}_{13} \mathrm{H}_{18} \mathrm{ClFeN}$ requires $\mathrm{C}, 55.85, \mathrm{H}, 6.49$; N, 5.00. Crystals were obtained by slow concentration of solutions in $\mathrm{CH}_{3} \mathrm{CN}$.

\subsection{Trapping experiment with $\mathrm{NEt}_{3}$}

$\mathrm{FcCH}_{2} \mathrm{NMe}_{2}(0.39 \mathrm{~g}, 1.6 \mathrm{mmol})$ was dissolved in 25 $\mathrm{ml}$ of $\mathrm{CH}_{2} \mathrm{Cl}_{2}$ and solid $\mathrm{NaSbF}_{6}(0.83 \mathrm{~g}, 0.32 \mathrm{mmol})$ and $\mathrm{NEt}_{3}$ (2.50 g, $24.6 \mathrm{mmol}, 15$ equivalents) were added. The mixture was stirred at room temperature for 3 days, and the orange-red suspension filtered over cannula. The solvent and the amine were distilled off and the oily residue chromatographed on neutral alumina with $\mathrm{H}_{2} \mathrm{O}$ /

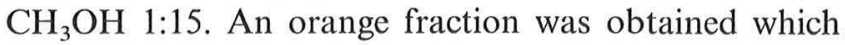
was immediately followed by a second, darker orange fraction. Both were dried over anhydrous $\mathrm{MgSO}_{4}$, filtered and the solutions concentrated in vacuo. From the first fraction large orange needles soon formed. After $5 \mathrm{~h}$ the mother liquor was pipetted off and the crystalline material dried in vacuo. The second fraction gave a yellow oil which very slowly crystallized. Both samples were found to contain $\left(\mathrm{FcCH}_{2}\right)_{2} \mathrm{NMe}_{2}^{+}$and $\mathrm{FcCH}_{2} \mathrm{NEt}_{3}^{+}$, albeit in a somewhat different product distribution. Combined yield: $0.385 \mathrm{~g}$.

\subsection{Reaction of $\mathrm{FCCH}_{2} \mathrm{NMe}_{2}$ with acetyl chloride}

$\mathrm{FcCH}_{2} \mathrm{NMe}_{2}(0.698 \mathrm{~g}, 2.87 \mathrm{mmol})$ was suspended in $\mathrm{Et}_{2} \mathrm{O}$ and small portions of $\mathrm{CH}_{3} \mathrm{CN}$ (ca. $4 \mathrm{ml}$ total) were added until a clear solution had formed. A solution of $\mathrm{CH}_{3} \mathrm{COCl}(100 \mu \mathrm{l}, 1.43 \mathrm{mmol})$ in $8 \mathrm{ml}$ of $\mathrm{Et}_{2} \mathrm{O}$ was added dropwise within $30 \mathrm{~min}$. A bright orange powder imme- 
Table 6

Experimental data for the X-ray structure determinations

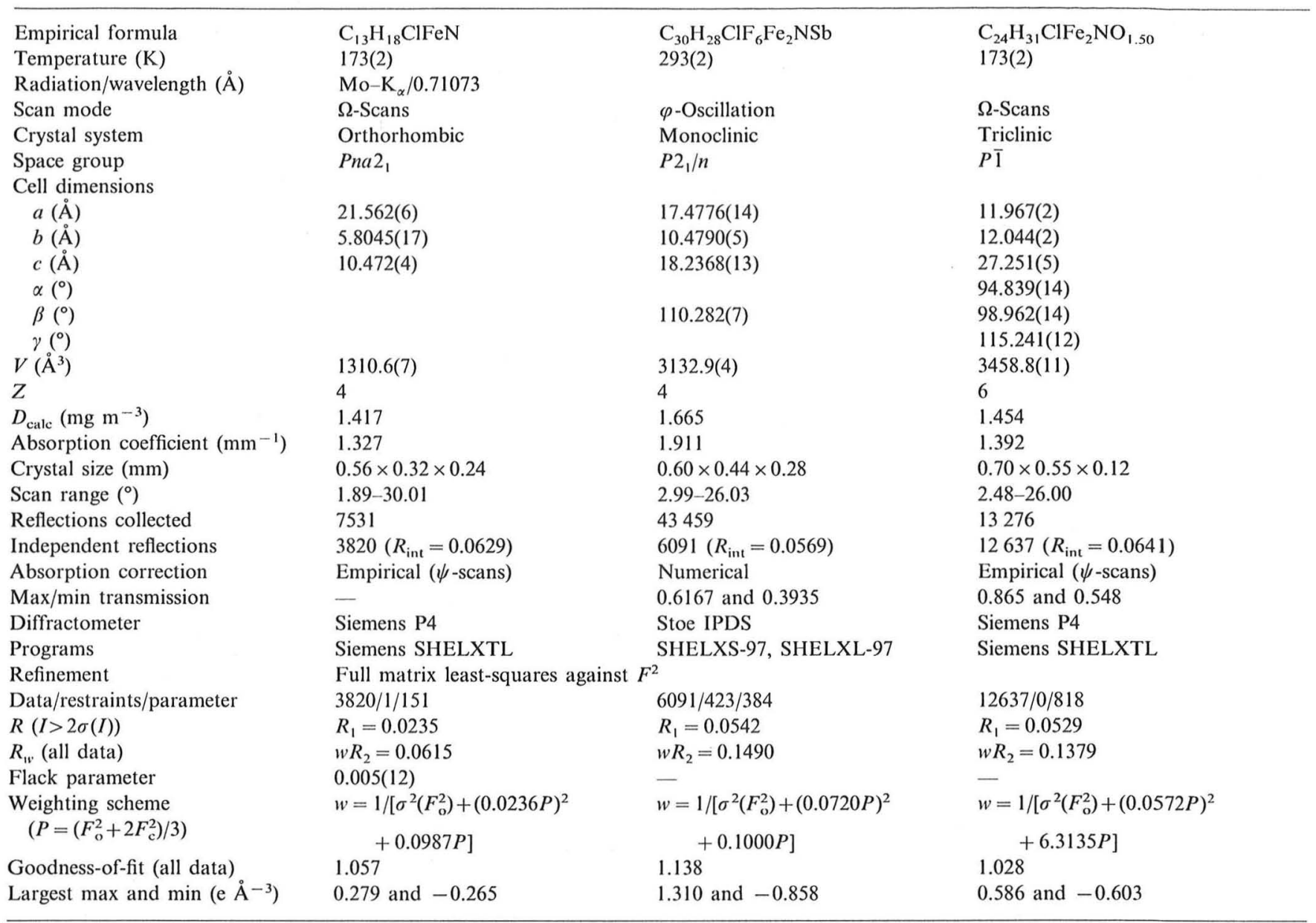

diately precipitated from solution. After the addition was complete, the solution was stirred for further $2 \mathrm{~h}$ and then filtered via a paper tipped cannula. The orange solid was washed three times with $5 \mathrm{ml}$ portions of $\mathrm{Et}_{2} \mathrm{O}$ each and then dried in vacuo to give pure $\left(\mathrm{FcCH}_{2}\right)_{2} \mathrm{NMe}_{2}^{+} \mathrm{Cl}^{-}$. Yield: $0.600 \mathrm{~g}, 88 \%$.

\subsection{Oxidation of $\mathrm{FcCH}_{2} \mathrm{NMe}_{2} \mathrm{H}^{+} \mathrm{SbF}_{6}^{-}$by $\mathrm{NO}^{+} \mathrm{SbF}_{6}^{-}$}

$\mathrm{FcCH}_{2} \mathrm{NMe}_{2} \mathrm{H}^{+} \mathrm{SbF}_{6}^{-}(0.042 \mathrm{~g}, 87.5 \mu \mathrm{mol})$ was dissolved in $1 \mathrm{ml}$ of degassed $\mathrm{CH}_{3} \mathrm{CN}$ and solid $\mathrm{NO}^{+} \mathrm{SbF}_{6}^{-}(0.023 \mathrm{~g}, 86 \mu \mathrm{mol})$ was added. The solution rapidly turned intense green and was purged with $\mathrm{Ar}$ for $30 \mathrm{~min}$. The product was then precipitated as a tar by addition of $\mathrm{Et}_{2} \mathrm{O}(3 \mathrm{ml})$. After syringing off the mother liquor and briefly drying in vacuo, the material was redissolved in the minimum amount of $\mathrm{CH}_{3} \mathrm{CN}$ and this solution very slowly added to $5 \mathrm{ml}$ of cold, rapidly stirred $\mathrm{Et}_{2} \mathrm{O}$. The mother liquor was again removed by a fine pipette and the residue dried in vacuo at elevated temperatures. The product was obtained as a dark blue-green, brittle solid. Yield: $0.047 \mathrm{~g}, 75 \%$. UV-vis $\lambda$ $(\mathrm{nm})\left(\varepsilon\left(\mathrm{M}^{-1} \mathrm{~cm}^{-1}\right)\right) 672(500), 580(\mathrm{sh})(280), 540(\mathrm{sh})$
(175), 468 (135), 360 (2500). Anal. found: C, 21.55; H, 2.46; N, 2.03. $\mathrm{C}_{13} \mathrm{H}_{18} \mathrm{~F}_{12} \mathrm{FeNSb}_{2}$ requires $\mathrm{C}, 21.82, \mathrm{H}$, 2.54; N, 1.97. IR: $v$ (cation) $3420(\mathrm{~s}), 3125(\mathrm{~m}), 2963(\mathrm{~m})$, 2730(m), 2724(m), 1475(m), 1419(m), 1261(s), 1162(w), 1104(s), 1100(s) 1027(s), 1014(m), 952(w), 919(w), 863(m), 802(s), 486(w), 401(w), 277(vs).

\subsection{Oxidation of $\left(\mathrm{FcCH}_{2}\right)_{2} \mathrm{NMe}_{2}^{+} \mathrm{Cl}^{-}$with $\mathrm{Ag}^{+} \mathrm{BF}_{4}^{-}$}

$\left(\mathrm{FcCH}_{2}\right)_{2} \mathrm{NMe}_{2}^{+} \mathrm{Cl}^{-}$(1d) $(0.12 \mathrm{~g}, 0.26 \mathrm{mmol})$ was dissolved in $\mathrm{CH}_{2} \mathrm{Cl}_{2}(20 \mathrm{ml})$. Upon addition of solid $\mathrm{AgBF}_{4}(0.15 \mathrm{~g}, 0.78 \mathrm{mmol})$ the color of the solution immediately changed to dark blue-green and a precipitate formed (note that the potential of the $\mathrm{Ag}^{0 /+}$ couple is strongly solvent dependent [60] and that $\mathrm{Ag}^{+}$is a strong enough oxidant to effect the conversion of $\left(\mathrm{FcCH}_{2}\right)_{2} \mathrm{NMe}_{2}^{+}$to its trication in $\mathrm{CH}_{2} \mathrm{Cl}_{2}$ but not in $\mathrm{CH}_{3} \mathrm{CN}$ ). The suspension was stirred for $2 \mathrm{~h}$ at room temperature and then filtered via a paper tipped cannula. The residue was dried in vacuo, extracted into $\mathrm{CH}_{3} \mathrm{NO}_{2}(2 \times 5 \mathrm{ml})$ and filtered by cannula. After concentration to ca. $2 \mathrm{ml}$ in vacuo, ether was added to precipitate the product as a heavy dark blue oil which 
was dried in vacuo for several hours. The product was obtained as a hard brittle intense colored solid. The presence of both $\mathrm{CH}_{3} \mathrm{NO}_{2}$ and $\mathrm{CH}_{2} \mathrm{Cl}_{2}$ in this solid was revealed by NMR-spectroscopy. Yield: $0.179 \mathrm{~g}, 81 \%$. Anal. found: C, 39.44; H, 3.98; N, 2.70. $\mathrm{C}_{24} \mathrm{H}_{28} \mathrm{~B}_{3} \mathrm{~F}_{12} \mathrm{Fe}_{2} \mathrm{~N} \times 2 / 3 \mathrm{CH}_{3} \mathrm{NO}_{2} \times 1 / 5 \mathrm{CH}_{2} \mathrm{Cl}_{2}$ requires $\mathrm{C}, 39.85, \mathrm{H}, 4.07 ; \mathrm{N}, 3.15$. UV-vis $\lambda(\mathrm{nm})\left(\varepsilon\left(\mathrm{M}^{-1}\right.\right.$ $\left.\left.\mathrm{cm}^{-1}\right)\right) 627$ (670), 580(sh) (350), 535(sh) (280), 471 (270), 380(sh) (600). IR $\vee\left(\mathrm{cm}^{-1}\right) 3116(\mathrm{~m}), 2960(\mathrm{w})$, 1635(m), 1560(m), 1482(m), 1418(m), 1394(w), 1287(m), 1262(m), 1247(m), 1083(vs), 1031(vs), 909(m), 859(s), 763(m), 521(m).

\subsection{3. $X$-ray structures}

Experimental data pertaining to the X-ray structures have been summarized in Table 6. Hydrogen atoms were positioned geometrically. A riding model was assumed for refinement of those atoms with isotropic thermal parameters being 1.5 times $\left(\mathrm{CH}_{3}\right.$-groups $)$ and 1.2 times $\left(\mathrm{Cp}-\mathrm{H}, \mathrm{CH}-\mu, \mathrm{CH}_{2}\right.$-groups) the values of the carrier carbon atoms.

For $1 \mathrm{~b}$ the anion and the solvent molecules are disordered. A fixed geometry was applied for the latter. In $\mathbf{1 d}, \mathrm{Cl}(3)$ is statistically replaced by $\mathrm{CN}^{-}$(C(999), $\mathrm{N}(4)$ ). The cif-files have been deposited at the Cambridge Structure Data Centre, University Chemical Laboratory, Lensfield Road, Cambridge, CB2 1EZ (deposition number CCDC-101 238).

\section{Supporting material}

Tables containing the fractional atomic coordinates and isotropic displacement parameters for $\mathbf{2 d}, \mathbf{1 b}$ and 1d $\cdot 4 / 3 \mathrm{H}_{2} \mathrm{O}$ (Tables $\mathrm{S} 1-\mathrm{S} 3$ ).

\section{Acknowledgements}

R.F.W. gratefully acknowledges financial support of this work by the Deutsche Forschungsgemeinschaft, Professor Dr Wolfgang Kaim and the Institut für Anorganische Chemie der Universität Stuttgart. We also wish to thank Birgit Brunner for her contributions within an advanced laboratory course and Dr Frank Baumann and Matthias Wanner for the recording of the ESR spectra.

\section{References}

[1] R.F. Winter, F.M. Hornung, Organometallics 21 (1997) 4248

[2] J.E. Mills, C.A. Maryanoff, R.M. Cosgrove, L. Scott, D.F. McComsey, Org. Prep. Proc. Int. 16 (1984) 97 and references therein.
[3] G.O. Nevstad, J. Songstad, Acta Chem. Scand. Ser. B 38 (1984) 469.

[4] B. Almarzoqi, A.V. George, N.S. Isaacs, Tetrahedron 42 (1986) 601.

[5] R.E. Banks, M.K. Besheesh, S.N. Mohialdin-K haffaf, I. Sharif, J. Flourine Chem. 78 (1996) 43.

[6] J.E. Mills, C.A. Maryanoff, D.F. McComsey, R.C. Stanzione, L. Scott, J. Org. Chem. 52 (1987) 1857.

[7] K. Matsumoto, T. Uchida, S. Hashimoto, Y. Yonezawa, H. Iida, A. Kakehi, S. Otani, Heterocycles 36 (1993) 2215.

[8] Y.-S. Hon, F.-J. Chang, L. Lu, J. Chem. Soc.; Chem. Comm. (1994) 2041.

[9] G. Kaupp, K. Sailer, J. Prakt. Chem. 338 (1996) 47.

[10] In the presence of oxygen strong acids may additionally oxidize the ferrocene moiety: (a) R. Prins, A.R. Korswagen, J. Organomet. Chem. 25 (1970) C74. (b) Gmelin Handbuch der Anorganischen Chemie, Bd. 14, A1, Springer, Berlin, 1974, p. 104.

[11] V.I. Boev, A.V. Dombrovskii, J. Gen. Chem. USSR 46 (1976) 1781.

[12] (a) M.I. Bruce, P. Hinterding, P.J. Low, B.W. Skelton, A.H. White, J. Chem. Soc.; Chem. Comm. (1996) 1009. (b) M.I. Bruce, P. Hinterding, M. Ke, P.J. Low, B.W. Skelton, A.H. White, J. Chem. Soc.; Chem. Comm. (1997) 715.

[13] Gmelin Handbuch der Anorganischen Chemie, Bd. 18, Antimon, Band C, 406, Gmelin-Verlag, Clausthal Zellerfeld, 1949; see also Na, Erg. Bd. 4, 1676, Verlag Chemie, Weinheim, Bergstraße and the information provided by the chemical suppliers.

[14] J.M. Coddington, M.J. Taylor, Spectrochim. Acta 46A (1990) 1487.

[15] (a) K. Schlögl, Monatsh. Chem. 88 (1957) 601. (b) Gmelin Handbuch der Anorganischen Chemie, Bd. 14, Al, Springer, Berlin, 1974, p. 43.

[16] (a) H. Böhme, W. Krause, Chem. Ber. 84 (1951) 170. (b) H. Böhme, E. Mundlos, O.E. Herboth, Chem. Ber. 90 (1957) 2003.

[17] H. Böhme, K. Hartke, Chem. Ber. 93 (1960) 1305.

[18] C. Rabiller, J.P. Renou, G.J. Martin, J. Chem. Soc. Perkin Trans. 2 (1977) 536.

[19] F. Knoll, U. Krumm, Chem. Ber. 104 (1971) 31.

[20] A.A. Pendin, P.K. Leont'evskaya, T.L. L'vova, B.P. Nikol'skii, Dokl. Phys. Chem. Proc. Acad. Sci. USSR 184 (1969) 717.

[21] R.G. Pearson, D.C. Vogelsong, J. Am. Chem. Soc. 80 (1958) 1038.

[22] The ${ }^{1} \mathrm{H}$-NMR shift values of $\mathrm{NMe}_{2} \mathrm{H}$ in $\mathrm{CCl}_{4}$ were obtained from H. Suhr, Chem. Ber. 96 (1963) 1720; the ${ }^{13} \mathrm{C}$ data in toluene- $\mathrm{D}_{8}$ are given by R.K. Kanjolia, L.K. Krannich, C.L. Watkins, J. Chem. Soc.; Dalton Trans. (1986) 2345.

[23] Gmelin Handbuch der Anorganischen Chemie, Bd. 14, A4, Springer, Berlin, 1980, p. 71.

[24] V.P. Tverdokhlebov, I.V. Tselinskii, N.Yu. Vasil'eva, J. Org. Chem. USSR 14 (1978) 985.

[25] (a) E.A. Hill, J. Org. Chem. 28 (1963) 3586. (b) T.T. Tidwell, T.G. Traylor, J. Am. Chem. Soc. 88 (1966) 3442.

[26] T.D. Turbitt, W.E. Watts, J. Chem. Soc., Chem. Commun. (1971) 631. (b) T.D. Turbitt, W.E. Watts, J. Chem. Soc.; Perkin Trans. 2 (1974) 195.

[27] An exhaustive overview of the older literature is given in Gmelin Handbuch der Anorganischen Chemie, Bd. 14, Al, Springer, Berlin, 1974, p. 349.

[28] (a) A.A. Korizde, N.M. Astakhova, P.V. Petrovskii, J. Organomet. Chem. 254 (1983) 345. (b) A. Houlton, J.R. Miller, R.M.G. Roberts, J. Silver, J. Chem. Soc., Dalton Trans. (1986) 2345.

[29] H.A. Hagemann, Org. React. 7 (1953) 205.

[30] J.H. Cooley, E.J. Evain, Synthesis (1989) 1.

[31] Y.A. Strepikheev, T.G. Perlova, L.A. Zhivechkova, J. Org. Chem. USSR 4 (1968) 1826. 
[32] (a) R.A. Olofson, T.J. Martz, J.-P. Senet, M. Piteau, T. Malfroot, J. Org. Chem. 49 (1984) 2081. (b) R.A. Olofson, D.E. Abbott, J. Org. Chem. 49 (1984) 2795. (c) A.L. Campbell, D.R. Pilipauskas, I.K. Khanna, R.A. Rhodes, Tetrahedron Lett. 28 (1987) 2331.

[33] R.A. Olofson, R.C. Schnur, L. Bunes, J.P. Pepe, Tetrahedron Lett. (1977) 1567.

[34] J.D. Hobson, J.G. McCluskey, J. Chem. Soc. C (1967) 2015.

[35] (a) J.T. Leffek, F.H.-C. Tsao, Can. J. Chem. 46 (1968) 1215. (b) J.T. Burns, K.T. Leffek, Can. J. Chem. 47 (1969) 3725. (c) L.W. Deady, O.L. Koritsky, Tetrahedron Lett. 20 (1979) 451.

[36] S.C. Jain, R. Rivest, J. Inorg. Nucl. Chem. 32 (1970) 1579.

[37] D.W. Slocum, R.L. Marchal, W.E. Jones, J. Organomet. Chem. 72 (1974) 227.

[38] A.A. Korizde, P.V. Petrowskii, A.I. Mokhov, A.I. Lutsenko, J. Organomet. Chem. 136 (1977) 57.

[39] C.S. Gibbons, J. Trotter, J. Chem. Soc. (A) (1971) 2659.

[40] Y. Zhang, Z. Cai, Z. Chen, K. Pan, G. Zhang, Z. Zhang, J. Struct. Chem. (China) 2 (1983) 206.

[41] (a) Z. Fu, K. Pan, J. Lu, G. Zhang, H. Zhu, J. Struct. Chem. (China) 2 (1983) 57. (b) Y. Zhang, Z. Cai, Z. Chen, K. Pan, J. Lu, G. Zhang, H. Zhu, J. Struct. Chem. (China) 1 (1982) 46.

[42] G. Ferguson, J.F. Gallagher, C. Glidewell, C.M. Zakaria, Acta Cryst. B50 (1994) 146.

[43] P.L. Veya, J.K. Kochi, J. Organomet. Chem. 488 (1995) 4.

[44] U. Siriwardane, S.S.C. Chu, N.S. Hosmane, H. Zhu, G. Zhang, Acta Cryst. C45 (1989) 333.

[45] H. Plenio, J. Yang, R. Diodone, J. Heinze, Inorg. Chem. 33 (1994) 4098

[46] R.S. Nicholson, I. Shain, Anal. Chem. 36 (1964) 706.

[47] J.E. Dubois, A. Monvernay, P.C. Lacaze, Electrochim. Acta 15 (1970) 315.
[48] (a) U. Siemeling, P. Jutzi, E. Bill, A.X. Trautwein, J. Organomet. Chem. 463 (1993) 151 and references therein. (b) H. Atzkern, J. Hiermeier, F.H. Köhler, A. Steck, J. Organomet. Chem. 408 (1991).

[49] (a) D.R. Talham, D.W. Cowan, Organometallics 6 (1987) 932. (b) B. Bildstein, P. Denifl, K. Wurst, M. André, M. Baumgarten, J. Friedrich, E. Elmerer-Müller, Organometallics 14 (1995) 4334.

[50] (a) N. Van Order, Jr., W.E. Geiger Jr., T.E. Bitterwolf, A.L. Rheingold, J. Am. Chem. Soc. 109 (1987) 5680. (b) W.E. Geiger, N. Van Order, Jr., D.T. Pierce, T.E. Bitterwolf, A.L. Rheingold, N.D. Chasteen, Organometallics 10 (1991) 2403.

[51] (a) F. Ammar, J.M. Savéant, J. Electroanal. Chem. 47 (1973) 215. (b) J.B. Flanagan, S. Margel, A.J. Bard, J. Am. Chem. Soc. 100 (1978) 4248.

[52] J.W. Hershberger, R.J. Klingler, J.K. Kochi, J. Am. Chem. Soc. 105 (1983) 61.

[53] This value was also used to calculate the electroactive surface of the working electrodes applied in this study.

[54] A.S. Baranski, W.R. Fawcett, C.M. Gilbert, Anal. Chem. 57 (1985) 166.

[55] (a) R.L. Myers, I. Shain, Anal. Chem. 41 (1960) 980. (b) D.E. Richardson, H. Taube, Inorg. Chem. 20 (1981) 1278.

[56] (a) N.S. Hush, Prog. Inorg. Chem. 30 (1983) 441 . (b) C. Creutz, Prog. Inorg. Chem. 30 (1983) 1.

[57] (a) K.D. Warren, Struct. Bonding (Berlin) 27 (1976) 45 and references therein. (b) G.A. Ozin, J. Godber, J. Phys. Chem. 93 (1989) 878.

[58] See for example: H. Günther, NMR-Spektroskopie, Georg Thieme Verlag, Stuttgart, 1992, pp. 427-429.

[59] G. Costa, A. Camus, L. Gatti, J. Organomet. Chem. 8 (1967) 339.

[60] N.G. Connelly, W.E. Geige, Chem. Rev. 96 (1996) 877. 